\title{
An assessment of the hydrogeochemistry of two wetlands located in Bihar State in the subtropical climatic zone of India
}

\author{
Ravi Ranjan ${ }^{1}$ Sunil Kumar Srivastava ${ }^{2}$ A. L. Ramanathan ${ }^{1}$
}

Received: 26 March 2016/ Accepted: 7 December 2016

(C) Springer-Verlag Berlin Heidelberg 2016

\begin{abstract}
A total of 30 water samples and 8 sediment samples were collected and chemically analysed for major ions $\mathrm{Na}^{+}, \mathrm{K}^{+}, \mathrm{Mg}^{2+}, \mathrm{Ca}^{2+}, \mathrm{HCO}_{3}{ }^{-}, \mathrm{SO}_{4}{ }^{2-}, \mathrm{Cl}^{-}, \mathrm{NO}_{3}{ }^{-}$, silica, $\mathrm{PO}_{4}{ }^{3-}, \mathrm{F}^{-}$), trace elements ( $\mathrm{Fe}, \mathrm{Mn}, \mathrm{Ni}, \mathrm{Cd}, \mathrm{Zn}, \mathrm{Pb}$, $\mathrm{Cu}$ ), minerals and nutrients to determine the factors that control the chemistry of water in the Kawar-Tal and Kusheshwar-Asthan wetlands in the Bihar State of India. These analyses indicate that $\mathrm{Ca}^{2+}$ and $\mathrm{HCO}_{3}{ }^{-}$ions are the most dominant ions in both of the wetlands. It also indicates rock weathering is a major source of ions in these wetlands, particularly the dissolution of carbonate minerals. The hydrogeochemistry of water in KusheshwarAsthan is favouring kaolinite formation and in Kawar-Tal favouring kaolinite-gibbsite formation. Quartz ( 36\%), clay minerals $(\sim 21 \%)$ and chlorite $(\sim 10 \%)$ are the dominant minerals in both the wetlands. Orthoclase $(\sim 12.49 \%)$, calcite $(\sim 7.51 \%)$ and illite $(4.89 \%)$ minerals are only available in Kawar-Tal surface sediment, while albite $(6.29 \%)$ and biotite $(\sim 13.6 \%)$ minerals are only available in Kusheshwar-Asthan. Total carbon $(\sim 3 \%)$, inorganic carbon $(0.9 \%)$, organic carbon $(\sim 2.1 \%)$, total sulphur $(\sim 0.0008 \%)$, nitrogen $(\sim 0.55 \%)$ and phosphate $(\sim 0.96 \%)$ are available in Kawar-Tal surface sediments, while total carbon $(\sim 2.38 \%)$, inorganic carbon $(0.55 \%)$, organic carbon $(\sim 1.84 \%)$, total sulphur $(\sim 0.001 \%)$, nitrogen $(\sim 0.62 \%)$ and phosphate $(\sim 0.64 \%)$ are available
\end{abstract}

Sunil Kumar Srivastava

suni116sster@gmail.com

1 School of Environmental Sciences, Jawaharlal Nehru University (JNU), New Delhi 110067, India

2 Department of Chemistry/Chemical Engineering, Jaypee University of Engineering and Technology (JUET), Guna 473226, India in Kusheshwar-Asthan surface sediments. The study indicates wetlands are rich in nutrient for biological activities and are sufficient to support the biodiversity, but few locations are influenced by anthropogenic activities which cause the increase of sulphur, chloride, iron and lead.

Keywords Hydrogeochemistry · Kawar-Tal · Kusheshwar-Asthan $\cdot$ Bihar $\cdot$ Wetland

\section{Introduction}

Wetlands are areas where water is the primary factor controlling the environment and the associated plant and animal life (Ramasar 2007). The UNEP-World Conservation Monitoring Center has suggested that wetlands cover a land area of about 570 million hectares, roughly $6 \%$ of the Earth's land surface, of which $2 \%$ is lakes, $30 \%$ bogs, $26 \%$ fens, $20 \%$ swamps and 15\% floodplains (Ramasar 2007). India has a rich variety of wetland habitats. The total area of wetlands (excluding rivers) in India is $58,286,000$ ha or $18.4 \%$ of the country, $70 \%$ of which comprises areas under paddy cultivation (Green 1990). A total of 1193 wetlands, covering an area of about 3,904,543 ha, were recorded in a preliminary inventory coordinated by the Department of Science and Technology (DST), of which 572 were natural (Green 1990). In a recent review of the India's wetlands, 93 were identified as being of conservation importance (Scott 1989). India's 19 most important wetlands that cover a total area of 648,507 ha have been designated under the convention of wetlands of international importance as being especially significant waterfowl habitats (Ramsar Convention 2003). The interactions of physical, biological and chemical components of a wetland, such as soils, water, plants and animals, enable the wetland to perform 
many vital functions, e.g. water storage; storm protection and flood mitigation; shoreline stabilization and erosion control; groundwater recharge and discharge; water purification through retention of nutrients in sediments; and stabilization of local climate conditions, particularly rainfall and temperature (Voogt et al. 2000).

Kawar-Tal is a largest freshwater lake in northern Bihar (Ambastha et al. 2007). This lake has been declared and notified as a protected area under section 37 of the WildLife Protection Act 1972. Kawar-Tal has been also declared as one of the "bird sanctuaries" in 1989 by the State Government of Bihar (Anand and Joshi 2013). The Ministry of Environment and Forest (1989), Government of India, has also selected this lake as one of the 16 wetlands of the country for conservation and management, mainly due to its greater and enormous productive potential for attracting numerous migratory birds coming from remote part of the country and from Siberia beyond the Himalayas. This wetland lies between the Burhi Gandak, old Bagmati and the Kareh Rivers (Kawar Lake Blogspot 2011). This lake is formed by the meandering action of the Gandak River and is now a residual oxbow lake, one of the thousands in Bihar and Uttar Pradesh flood plains (Kawar Lake BlogSpot 2011). In years of high rainfall, vast areas of these two states get flooded (Irrigation and Water ways Department 2000). This causes a coalescing of wetlands form a single huge expanse of water. The floods leave behind deposits of sand, silt and clay in layers of varying thickness. In years of average rainfall, Kawar-Tal is connected with Burhi Gandak (a tributary of the River Ganga) and with nearby Nagri Jheel and Bikrampur Chaurs and unites to form a lake of about 7400 ha. By late summer, however, the water is confined to the deeper depressions and only about 300-400 ha of Kawar-Tal remains flooded and cuts off from the adjacent floodplains. The annual range of water temperature is $19.7-28.5^{\circ} \mathrm{C}$. This narrow temperature variation throughout the year helps support fish life in the wetland. Kawar-Tal Lake is surrounded by 16 villages with a population of several thousands and the people undertaking land uses that have the potential to affect water quality in the lake. This lake has very dense submerged vegetation which is rich in terms of biodiversity. There were altogether 51 species of fishes belonging to 15 families and 10 orders (Sharma et al. 1994). Investigations have shown that the lake has rich biotic potential with 55 species of macrophytes (Sharma 1995); 93 species of planktons; 87 species of macroinvertebrates (Sinha et al. 1994); 65 species of insects (Parkash and Kumar 1996); and 11 species of gastropods being recorded. In this wetland, around 59 species of migratory birds and 107 species of local birds have been also identified (Sharma et al. 1994).
Kusheshwar-Asthan is a vast wetland made up of the spilled water and river bed of the Kosi, the Kareh and the Kamla-Balan besides innumerable seasonal channels and gullies. The rivers and gullies bring silt and detrital organic matter which is deposited near river mouths, blocking their outflow. Hence, the river gets broken down into innumerable channels and rivulets. Further overbank flow of water and silt causes river diversions and creates oxbow lakes. During the rainy season, the water fills most parts ( 90\%) of Kusheshwar-Asthan. This water logging affects 14 villages of Kusheshwar-Asthan block covering an area of 2840.80 ha. Due to their greater ecological, faunal, floral and natural importance, this area has been declared as bird sanctuary (area around 6700 ha) under the WildLife Protection Act 1972 (as amended up to 1991) on 25 August 1994 by state government of the Bihar. This is one of the 13 sanctuaries of the state Bihar with Kawar-Tal Bird sanctuary, which is included in the international list by Bird Life International and Royal Society for Protection of Birds, UK. Due to fresh alluvial deposits and rich manures and nutrients, the soil of this area is very fertile which supports the biodiversity of wetland. A variety of zooplankton and phytoplankton thrive in this wetland under warm and humid conditions. This ecosystem attracts a lot of birds of different species for feeding and breeding. Many of the birds are endemic species along with few reported migratory birds. The migratory birds begin arriving in the beginning of the October, and they reside in the wetland up to March. This wetland also reported 87 species of fishes belonging to 20 different families, and 28 species of molluscs (gastropods 18 species and bivalves 10 species) have been recorded in this area so far (Munshi and Munshi 1991).

Both the wetlands are very important on basis of biodiversity and protected under national and international laws. It needs to be protected under this consideration; this study was carried out to predict the status of quality of lake water and sediment. By this, we can predict possible anthropogenic influences in these areas.

\section{Study area}

Water and sediment sampling was carried out in the two wetlands located in the subtropical climatic zone of the India. A total of 30 water samples and 8 sediment samples were collected from both the wetlands. Kawar-Tal is located in Manjhaul village of Cheria Bariarpur block of Begusarai District of the Bihar on the northern bank of the River Ganga. It is $22 \mathrm{~km}$ north of the Begusarai town. Geographically, it is located in between latitudes $25^{\circ} 36^{\prime}-$ $25^{\circ} 39^{\prime} \mathrm{N}$ and longitude $86^{\circ} 06^{\prime}-86^{\circ} 10^{\prime} \mathrm{E}$ (Fig. 1) . Kusheshwar-Asthan is $60 \mathrm{~km}$ away from the Darbhanga town. Geographically, it is located in between latitudes 

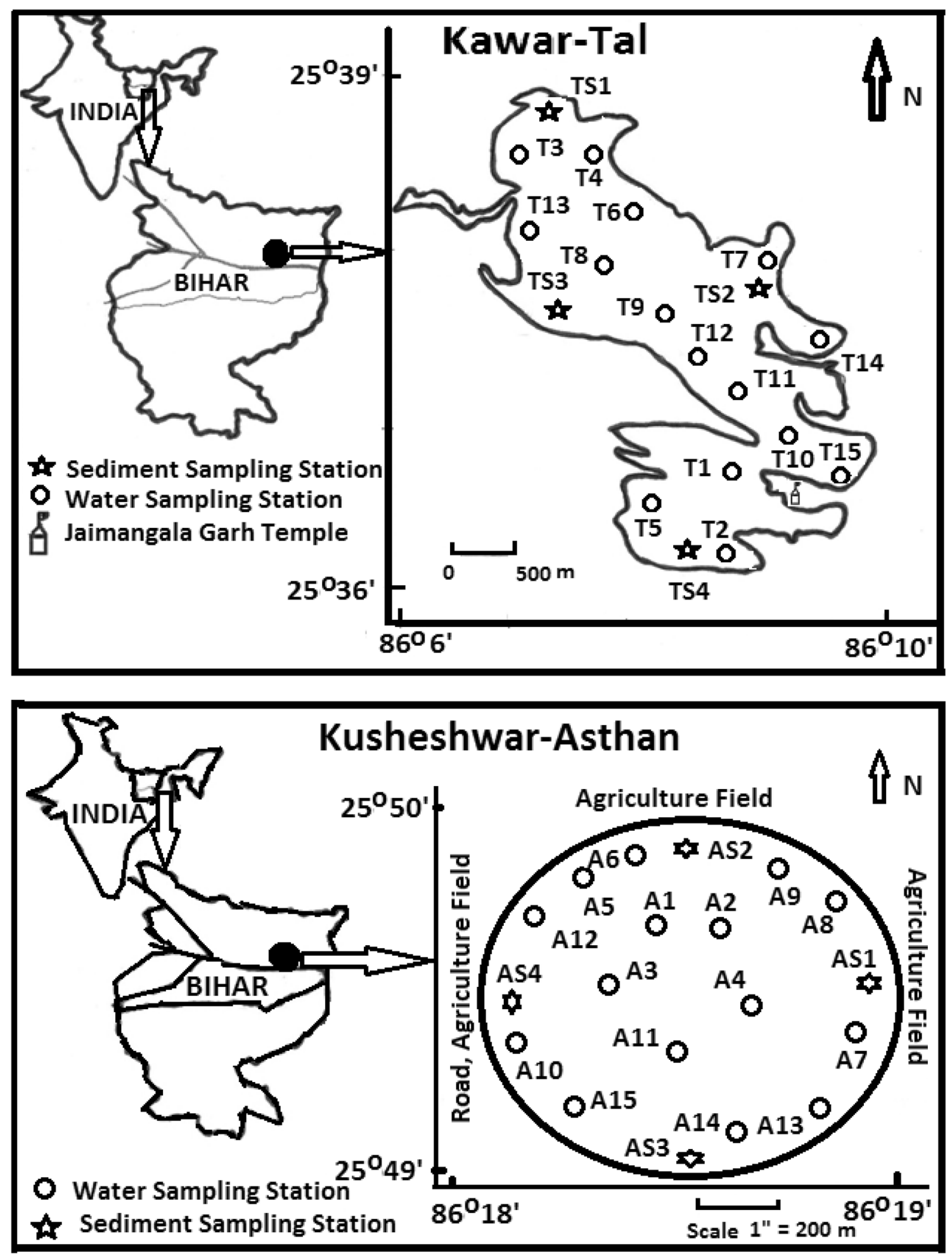

Fig. 1 Study area (showing sampling locations in Kawar-Tal and Kusheshwar-Asthan wetlands)

$25^{\circ} 49^{\prime}-25^{\circ} 50^{\prime} \mathrm{N}$ and longitude $86^{\circ} 18^{\prime}-86^{\circ} 19^{\prime} \mathrm{E}$ (Fig. 1). Being a part of the Gangetic Plain of the Indian subcontinent, these areas experience three climatic seasons-a hot and humid summer $\left(\sim 42{ }^{\circ} \mathrm{C}\right)$ period from late March to mid-June, a rainy season from mid-June to October and the winter season from the November to February. The average annual rainfall in this belt of the Ganga-Burhi and Gandak is $138.4 \mathrm{~cm}$, mostly $(\sim 83 \%)$ in between the months of June to October (Indian Meteorological Department 19902010). 
The surface is characterized by palaeolevees, swamps or flood basins (locally called "Chaurs"), relict palaeochannels aggraded in varying degrees, meander belts, oxbow lakes and cut-off loops. Its fluvial geomorphology is dominated from west to east by the GangaGandak interfluves, the Gandak-Kosi interfluves and the west by the Kosi fan belt. Some of these rivers frequently change their channels. Geomorphologically, these channels form a part of the Gandak-Kosi interfluves. The southern part of the district, except those of low-lying flood plains of the River Ganga, appears to be an elevated landmass when compared with the adjoining districts of the Khagaria and Samastipur. Hence, being a safer destination amidst the flood-drained region, it supports the human activities in a better way. In the River Ganga flood plain, which is approximately $50-55 \mathrm{~km}$ long and 5-6 km wide, in the southern part of the district, except those lowlying areas of "Taals and Chaurs", the typical fluvial characteristics of north Bihar rivers are not visible. This relatively upland area appears to be the levee of the River Ganga (Mahadevan 2002).

Geologically, the study area is an alluvial plain in the domain of the Himalayan Rivers to the north of the Ganga. It is a part of the great Gangetic Basin. The basin was formed during late Palaeogene-Neogene times and is related to the upheaval of the Himalayas viz. flexural down warp of the Indian Plate under the supracrustal load of the Himalayas (Wadia 1966). The entire segment abounds in buried faults and grabens. The basin came into existence as a result of the collision of the India and China continental plates during the Palaeocene (Dewey and Bird 1970). The collision has caused intraplate subduction along the main central thrust, lying in the Himalayas, raising the higher Himalaya to form source rocks and "popping through" the more southerly part of the Indian Plate to form the basin. This "popping through" might have lead to the development of longitudinal and transverse lineaments throughout the basin. With time, more southerly areas were raised, and by the mid-Palaeocene, subduction also started along the main boundary fault lying in the Himalayas.

The soil of this land unit is primarily unaltered alluvium, which is yet to undergo pedogenesis (process of soil formation). Texturally, it varies from sandy loam to loam in the meander scroll and levee (the upland bounding the flood plains of the river) areas to silt loam and silt in flood basin areas of the Himalayan Rivers and from loam in the levees of the Ganga to clayey loam and clay in the basin of the Burhi Gandak and the Bagmati River. The soil of the area is sandy loam rich with humus and is also very fertile (Mahadevan 2002).

\section{Methodology}

A well-planned inventory survey was carried out in the study area to understand the hydrogeochemistry of the wetlands in the month of December. A Garmin Global Positioning System (GPS) was used for fixing the suitable sampling locations to determine the hydrogeochemistry of both wetlands. Thirty water samples and 8 core sediment samples were collected in January 2005. The parameters $[\mathrm{pH}$, temperature, electrical conductivity (EC), dissolved oxygen (DO), oxidation-reduction potential (ORP), total dissolved solids (TDS) and total suspended matter (TSM)] were measured in the field at the time of sampling by using a water analyser kit, and these measurements were cross-checked in the laboratory. For cations, $100 \mathrm{~mL}$ samples were filtered using $0.45-\mu \mathrm{m}$ filter paper and preserved on site with ultrapure nitric acid (boric acid was used as a preservative for nitrate) and stored at $4{ }^{\circ} \mathrm{C}$ to avoid chemical alteration to samples during transport and holding (APHA 1995). Sodium and potassium were analysed by an AIMIL, PE I Flame Photometer following the standard method (APHA 1995). An atomic absorption spectrophotometer (Shimadzu-AA-6800) was used for analysis of heavy metals $(\mathrm{Mn}, \mathrm{Fe}, \mathrm{Ni}, \mathrm{Cu}, \mathrm{Zn}, \mathrm{Cd}$ and $\mathrm{Pb}$ ) and alkaline earth metals ( $\mathrm{Mg}$ and $\mathrm{Ca}$ ). Anions $\left(\mathrm{SO}_{4}{ }^{2-}, \mathrm{NO}_{3}{ }^{-}, \mathrm{F}^{-}, \mathrm{PO}_{4}{ }^{3-}\right.$ and silicate) were analysed by using a JENWAY $6505 \mathrm{UV} / \mathrm{Vis}$ spectrophotometer, using the standard method as given in APHA (1995). Bicarbonate and chloride were analysed by titration method using the standard procedure as given in APHA (1995).

Total Carbon (TC), inorganic carbon (IC), organic carbon (OC), total sulphur (TS), inorganic sulphur (IS) and organic sulphur (OS) were analysed in cores of sediments (free from halogen) by using Eltra (CS 1000) carbon/sulphur analyser as per standard procedure. For analysis of IC and IS, samples were further treated with $30 \%(\mathrm{v} / \mathrm{v}) \mathrm{H}_{2} \mathrm{O}_{2}$ to make it free from organic matter (Jackson 1973). Nitrogen was analysed by the Kjeldahl digestion method (Scheper et al. 2008). Analysis of major and minor elements was carried out by the two-solution method (Shapiro and Brannock 1962). Solution "A" was used for silica, phosphorous and aluminium. The mineralogy of surface sediment was studied by using X-Ray Diffractometer (XRD) (model Philips X'Pert). The slide was run through X-Ray Diffractometer (XRD) (model Philips X'Pert) at the rate of $2 \%$. For grain size analysis of the surface sediment, all the samples were air-dried and then oven-dried at $60{ }^{\circ} \mathrm{C}$ for $24 \mathrm{~h}$, and pebbles and very coarse materials were removed. The samples were thoroughly homogenized using a coning and quartering technique (Ingram 1971). Size separation of the sample grains was carried out 
following the standard sieving and sedimentation methods (Ingram 1971). The samples were dry-sieved on an electrically controlled electromagnetic sieve shaker (Fritsch Analysette-3) for $45 \mathrm{~min}$. Then, grain size fraction of $37-63 \mu \mathrm{m}$ and $<37 \mu \mathrm{m}$ (silt and clay); 63-125 $\mu \mathrm{m}$ (very fine sand); $125-150 \mu \mathrm{m}$ (fine sand); $250-600 \mu \mathrm{m}$ (medium sand); and $>600 \mu \mathrm{m}$ (coarse sand) was collected. The weights of all the fractions were taken out separately, and statistical calculations were made by the graph method (Krumbein and Pettijohn 1958; Lindholm 1987).

\section{Results and discussion}

The distribution pattern of major cations and anions in water samples of the both wetlands was as follows: $\mathrm{Ca}^{2+}>\mathrm{Na}^{+}>\mathrm{Mg}^{2+}>\mathrm{K}^{+}$and $\mathrm{HCO}_{3}{ }^{-}>\mathrm{Cl}^{-}>$ $\mathrm{SO}_{4}{ }^{2-}>\mathrm{NO}_{3}{ }^{-}>\mathrm{F}^{-}=\mathrm{PO}_{4}{ }^{3-}$. Most of the water samples showed a good charge balance with $\pm 5.0 \%$ error, which is generally considered acceptable because it is very difficult to analyse all cations and anions (Berner and Berner 1987; Edmond et al. 1995; Huh et al. 1998; Srivastava and
Ramanathan 2012). The investigation of various physicochemical parameters like $\mathrm{pH}, \mathrm{EC}, \mathrm{TDS}, \mathrm{ORP}, \mathrm{TSH}$ and DO of water samples indicates about the type of physicochemical and biological processes occurring in the wetland and its surrounding in catchments area. Investigation of grain size of sediment helps to understand the sediment characteristics, soil, rock type and weathering processes in the study area. It also helps to determine the depositional pattern in the environment. The texture and mineralogy of the sediments in the aquatic environment are useful for interpreting depositional environment, provenance and nutrient occurrence of the aquatic medium. Analysis of carbon, nitrogen and phosphate in the surface sediment helps to understand the biological activities in the wetlands.

\section{Water chemistry of wetlands}

The average, maximum, minimum and standard deviation for each water quality parameter were analysed for both the wetlands as shown in Table 1. Both wetlands' water was alkaline in nature $(\mathrm{pH} \sim 8.17)$ (Table 1). Alkaline water in
Table 1 Summary of statistics of chemical parameters of Kawar-Tal and KusheshwarAsthan Wetlands

\begin{tabular}{|c|c|c|c|c|c|c|c|c|}
\hline \multirow[t]{2}{*}{ Chemical parameter } & \multicolumn{4}{|c|}{ Kawar-Tal } & \multicolumn{4}{|c|}{ Kusheshwar-Asthan } \\
\hline & Min. & Max. & Avg. & SD & Min. & Max. & Avg. & SD \\
\hline DO (mg/L) & 8.09 & 8.77 & 8.38 & 0.17 & 7.61 & 8.72 & 8.26 & 0.28 \\
\hline TSM (mg/L) & 0.1 & 0.3 & 0.15 & NA & 0.2 & 0.6 & 0.44 & 0.13 \\
\hline ORP (mV) & 133 & 145 & 139.87 & 4.55 & 131 & 150 & 140.53 & 5.9 \\
\hline $\mathrm{pH}$ & 7.92 & 8.31 & 8.19 & 0.11 & 7.97 & 8.28 & 8.17 & 0.09 \\
\hline $\mathrm{EC}(\mu \mathrm{S} / \mathrm{cm})$ & 289 & 476 & 374.87 & 69.73 & 388 & 435 & 417.73 & 12.4 \\
\hline TDS (mg/L) & 191 & 317 & 248.6 & 46.38 & 258 & 288 & 276.93 & 8.58 \\
\hline $\mathrm{F}^{-}(\mathrm{mg} / \mathrm{L})$ & 0.11 & 0.37 & 0.22 & 0.11 & 0.1 & 0.32 & 0.19 & 0.07 \\
\hline $\mathrm{Cl}^{-}(\mathrm{mg} / \mathrm{L})$ & 26.72 & 36.51 & 29.61 & 2.55 & 42.04 & 54.29 & 49 & 3.43 \\
\hline $\mathrm{HCO}_{3}{ }^{-}(\mathrm{mg} / \mathrm{L})$ & 153.4 & 209.91 & 182.47 & 17.34 & 139.21 & 183.18 & 153.78 & 14.59 \\
\hline $\mathrm{SO}_{4}{ }^{2-}(\mathrm{mg} / \mathrm{L})$ & 10.34 & 11.52 & 10.82 & 0.39 & 26.02 & 32.54 & 27.64 & 1.63 \\
\hline $\mathrm{PO}_{4}{ }^{3-}(\mathrm{mg} / \mathrm{L})$ & 0.22 & 0.4 & 0.28 & 0.06 & 0.27 & 0.53 & 0.43 & 0.08 \\
\hline $\mathrm{H}_{3} \mathrm{SiO}_{4}{ }^{-}(\mathrm{mg} / \mathrm{L})$ & 0.07 & 3.14 & 1.22 & 1.01 & 5.6 & 8.07 & 6.15 & 0.62 \\
\hline $\mathrm{NO}_{3}{ }^{-}(\mathrm{mg} / \mathrm{L})$ & 1.56 & 3.91 & 2.84 & 0.69 & 3 & 6.89 & 5.08 & 0.91 \\
\hline $\mathrm{Ca}(\mathrm{mg} / \mathrm{L})$ & 33.48 & 59.79 & 45.37 & 9.56 & 39.91 & 54.99 & 43.24 & 3.84 \\
\hline $\mathrm{Mg}(\mathrm{mg} / \mathrm{L})$ & 7.45 & 14.44 & 10.65 & 2.53 & 8.88 & 10.79 & 10.02 & 0.89 \\
\hline $\mathrm{Na}(\mathrm{mg} / \mathrm{L})$ & 20.29 & 33.32 & 24.53 & 4.15 & 23.07 & 37.07 & 26.7 & 4.15 \\
\hline $\mathrm{K}(\mathrm{mg} / \mathrm{L})$ & 1.69 & 2.66 & 2.12 & 0.36 & 2.68 & 3.27 & 2.89 & 0.18 \\
\hline $\mathrm{Mn}(\mathrm{mg} / \mathrm{L})$ & 0.02 & 0.04 & 0.03 & 0.01 & 0.03 & 0.06 & 0.04 & 0.01 \\
\hline $\mathrm{Fe}(\mathrm{mg} / \mathrm{L})$ & 0.02 & 0.19 & 0.06 & 0.05 & 0.34 & 1.13 & 0.65 & 0.2 \\
\hline $\mathrm{Ni}(\mathrm{mg} / \mathrm{L})$ & 0.02 & 0.11 & 0.06 & 0.03 & 0.01 & 0.13 & 0.05 & 0.03 \\
\hline $\mathrm{Cu}(\mathrm{mg} / \mathrm{L})$ & 0.001 & 0.003 & 0.002 & NA & 0.001 & 0.005 & 0.004 & 0.001 \\
\hline $\mathrm{Zn}(\mathrm{mg} / \mathrm{L})$ & 0.01 & 0.07 & 0.02 & 0.02 & 0.01 & 0.03 & 0.02 & 0.01 \\
\hline $\mathrm{Cd}(\mathrm{mg} / \mathrm{L})$ & 0.02 & 0.03 & 0.02 & 0.005 & 0.01 & 0.03 & 0.02 & 0.01 \\
\hline $\mathrm{Pb}(\mathrm{mg} / \mathrm{L})$ & 0.34 & 0.54 & 0.46 & 0.07 & 0.41 & 0.59 & 0.49 & 0.05 \\
\hline
\end{tabular}

min. minimum, max. maximum, Avg. average, $S D$ standard deviation 
Table 2 Correlation matrix (Kawar-Tal)

\begin{tabular}{|c|c|c|c|c|c|c|c|c|c|c|c|c|c|}
\hline & $\mathrm{pH}$ & $\mathrm{EC}$ & TDS & $\mathrm{Ca}$ & $\mathrm{Mg}$ & $\mathrm{Na}$ & $\mathrm{K}$ & $\mathrm{Cl}^{-}$ & $\mathrm{HCO}_{3}{ }^{-}$ & $\mathrm{SO}_{4}{ }^{2-}$ & $\mathrm{NO}_{3}^{-}$ & $\mathrm{PO}_{4}{ }^{3-}$ & $\mathrm{F}^{-}$ \\
\hline $\mathrm{pH}$ & 1 & & & & & & & & & & & & \\
\hline $\mathrm{EC}$ & -0.52 & 1 & & & & & & & & & & & \\
\hline TDS & -0.52 & 1 & 1 & & & & & & & & & & \\
\hline $\mathrm{Ca}$ & -0.47 & 0.96 & 0.96 & 1 & & & & & & & & & \\
\hline $\mathrm{Mg}$ & -0.44 & 0.9 & 0.9 & 0.96 & 1 & & & & & & & & \\
\hline $\mathrm{Na}$ & 0.07 & -0.43 & -0.43 & -0.41 & -0.61 & 1 & & & & & & & \\
\hline K & -0.17 & 0.61 & 0.61 & 0.68 & 0.76 & -0.64 & 1 & & & & & & \\
\hline $\mathrm{Cl}^{-}$ & -0.43 & 0.26 & 0.27 & 0.27 & 0.27 & 0.13 & 0.07 & 1 & & & & & \\
\hline $\mathrm{HCO}_{3}{ }^{-}$ & -0.6 & 0.81 & 0.8 & 0.85 & 0.73 & -0.07 & 0.5 & 0.23 & 1 & & & & \\
\hline $\mathrm{SO}_{4}{ }^{2-}$ & -0.24 & -0.13 & -0.13 & -0.14 & -0.2 & 0.36 & 0.09 & 0.09 & 0.08 & 1 & & & \\
\hline $\mathrm{NO}_{3}^{-}$ & -0.33 & 0.28 & 0.29 & 0.45 & 0.53 & -0.09 & 0.44 & 0.5 & 0.32 & -0.03 & 1 & & \\
\hline $\mathrm{PO}_{4}{ }^{3-}$ & -0.36 & 0.03 & 0.03 & 0.12 & 0.13 & 0.26 & -0.15 & 0.7 & 0.13 & 0.15 & 0.49 & 1 & \\
\hline $\mathrm{F}^{-}$ & -0.01 & -0.22 & -0.22 & -0.28 & -0.21 & -0.24 & 0.03 & 0.23 & -0.27 & -0.07 & -0.19 & -0.22 & 1 \\
\hline
\end{tabular}

both wetlands may be due to natural processes of weathering, evaporation and $\mathrm{CO}_{2}$ gas equilibrium (Garrel and Mackenzie 1967). Araoye (2009), Goel et al. (1985) and Sarana and Adoni (1982) have shown the dependence of $\mathrm{pH}$ on the biological activities. King (1970); William et al. (1970); Olsen and Summerfield (1977); and Goldman (1972) have shown an increase in $\mathrm{pH}$ with active growth of phytoplankton. The high DO values in Kawar-Tal and Kusheshwar-Asthan can be related to high-level photosynthetic activity in the water bodies. A significant EC was reported in both wetlands, i.e. Kusheshwar-Asthan (417.73 $\mu \mathrm{S} / \mathrm{cm})$ and Kawar-Tal $(374.87 \mu \mathrm{S} / \mathrm{cm})$ (Table 1). A good correlation between $\mathrm{EC}$ and $\mathrm{Ca}^{2+}, \mathrm{Mg}^{2+}$ and $\mathrm{K}^{+}$ observed in Kawar-Tal water samples indicates a possible source of these ions from the weathering of clay minerals, which was also justified in the mineralogical study of sediments (Tables 2, 5).

$\underset{\text { Orthoclase }}{4 \mathrm{KAlSi}_{3} \mathrm{O}_{8}}+4 \mathrm{H}^{+}+\underset{\text { Kaolinite }}{2 \mathrm{H}_{2} \mathrm{O}} \rightarrow \underset{8}{4 \mathrm{~K}^{+}}+\underset{\mathrm{Al}_{4} \mathrm{Si}_{4} \mathrm{O}_{10}(\mathrm{OH})_{8}}{\mathrm{ASiO}_{2}}$

$\underset{\text { Calcite }}{\mathrm{CaCO}_{3}}+\mathrm{H}_{2} \mathrm{CO}_{3} \rightarrow \mathrm{Ca}^{2+}+2\left(\mathrm{HCO}_{3}^{-}\right)$

TDS/EC shows good correlation in both wetlands (with correlation coefficients of $\sim 0.67$; refer to Table 4 ). TDS shows some spatial variation in Kawar-Tal, but in Kusheshwar-Asthan value of TDS is almost constant throughout the wetland, possibly due to its smaller size uniform ecology. Water in Kawar-Tal (with a TDS of $0.15 \mathrm{mg} / \mathrm{L}$ ) has a lower content of suspended matter than Kusheshwar-Asthan (TDS $=0.44 \mathrm{mg} / \mathrm{L})$, maybe due to comparatively limited availability of clay minerals (Table 1, 5).

\section{Nutrients}

A significant concentration of nitrate and phosphate ions that were observed in the study areas indicates possible enrichment of nitrogen and phosphorous in the two wetlands (Table 1). It was observed that $\mathrm{NO}_{3}{ }^{-}$ions concentrations rapidly change in a water body, and it may be due to the prevailing biological activities in the system in both wetlands (Figs. 2d, 3d) (Wetzel 1979). Natural factors influencing the variability of phosphate and nitrate are considered to be associated with nitrogen and phosphorus cycle in the soil (biological sorption), especially during the growing season, when plants take up these macronutrients, mainly nitrogen, phosphorous and potassium from water (Kabata and Pendias 1999). According to Wetzel (1979), significant increases in the nutrient content in this wetland can be attributed to increased agricultural activities with increased use of fertilizers in the catchment areas. The contribution of nutrients by animal faeces cannot also be ruled out. Kawar-Tal is almost completely covered with aquatic vegetation; hence, concentration of nitrate and phosphate is less than Kusheshwar-Asthan, maybe due to consumption of nutrient by this aquatic vegetation. The problem of prolific growth of aquatic macrophytes in Kawar-Tal was already reported in the Conservation of Wetlands in India (Ministry of Environment and Forests 1989). A very low (0.11-0.32 mg/L) concentration of fluoride has been reported in both wetlands, and spatial variations in concentrations were also low (Table 1). The chloride ions concentrations are extremely variable and depend on the rock, soil and water interaction during runoff. The availability of chloride ions in water samples was $\sim 13 \%$ in Kawar-Tal and $\sim 20 \%$ in Kusheshwar-Asthan of 
Fig. 2 Graph of various chemical parameters (KawarTal)
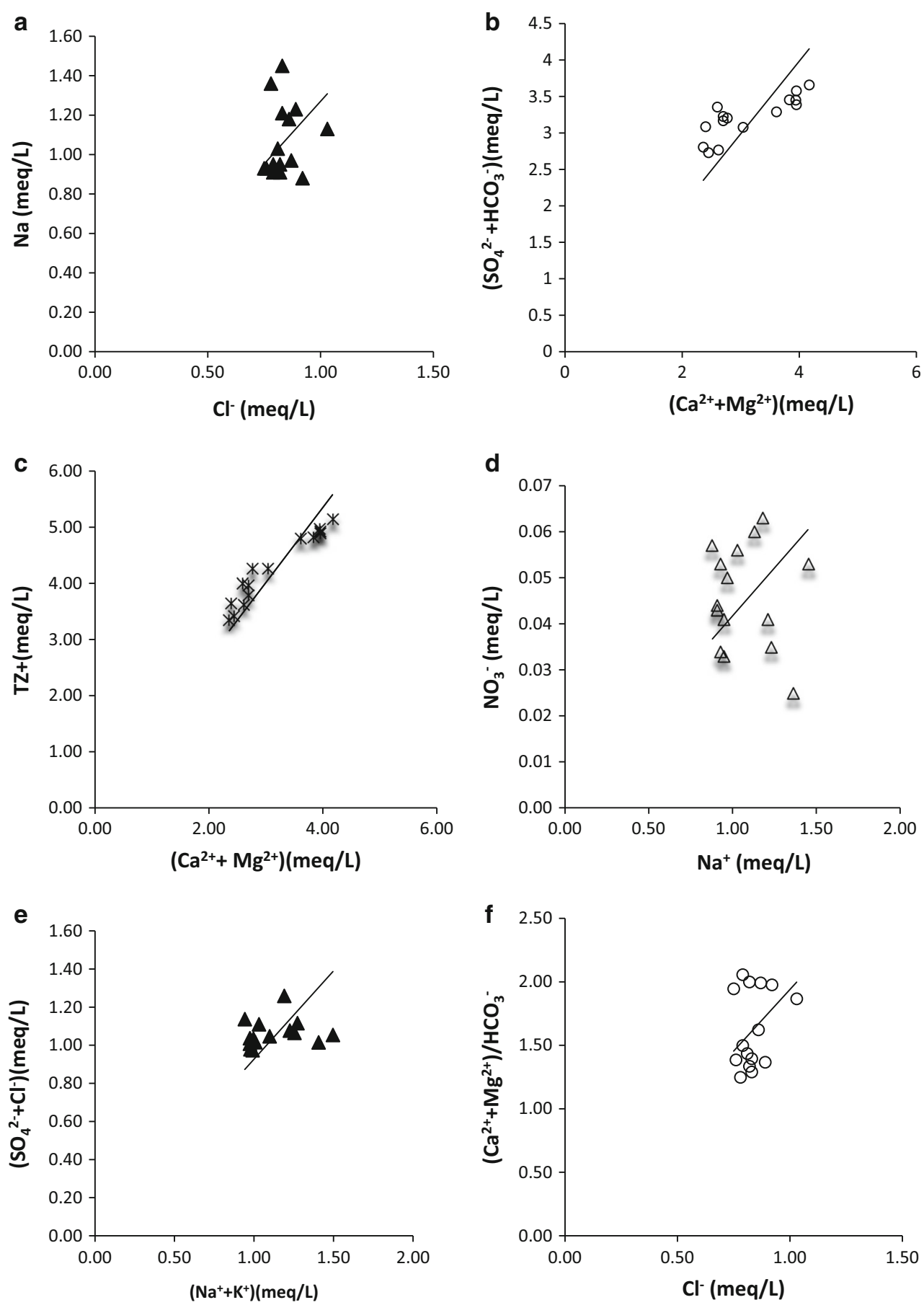

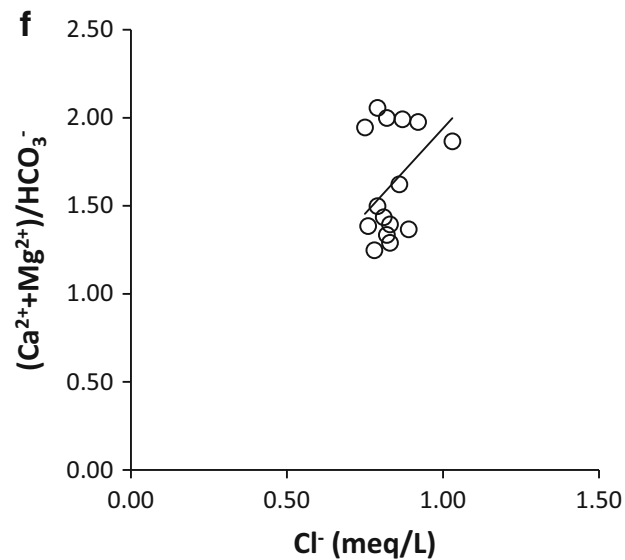

the total anions in the respective wetlands (Table 1). The presence of high chloride concentration in water has also been attributed to pollution (Taylor et al. 1958; Wetzel 1974). Pollution from industries and domestic effluents could also be a contributing factor to the high chloride content in the wetlands. Sulphate is often the second most abundant anion (after bicarbonate) in freshwaters considering the geology of study area, but in both wetlands, chloride is the second most anion (Table 1). Contribution of sulphate to the total anions was not much high on both the places. The major source of sulphate in water is the weathering of rocks, particularly pyrite, anhydrite and gypsum (Bell 1994; Hounslow 1995). The other possible source in wetlands is leaching of fertilizer (containing sulphate as important ingredient) along with rainwater through agriculture lands available in surrounding areas. These factors could have contributed to the sulphate content in the wetlands (Sigurdsson 1990; Giblin and Wieder 
Fig. 3 Graph of various chemical parameters (Kusheshwar-Asthan)
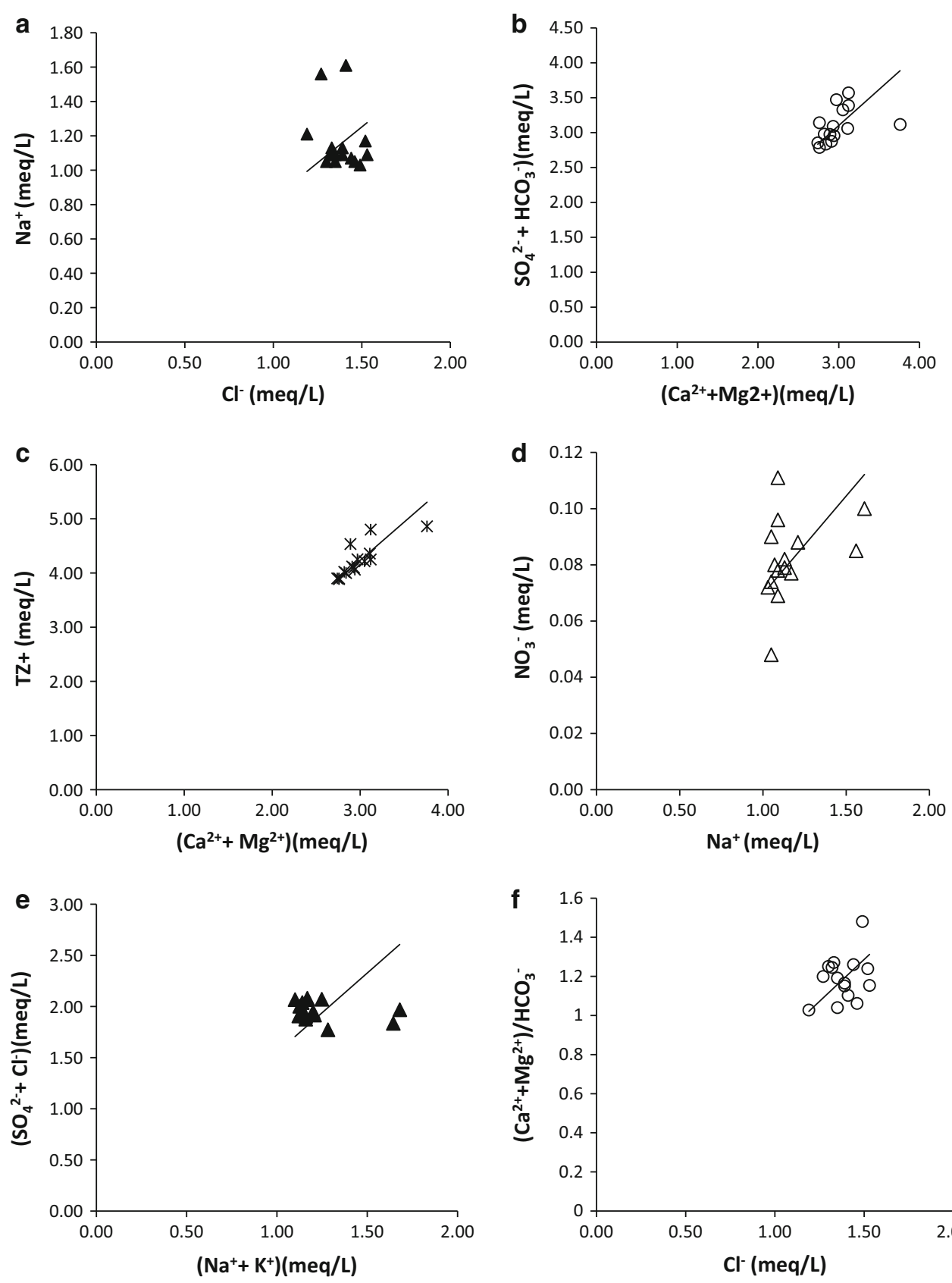

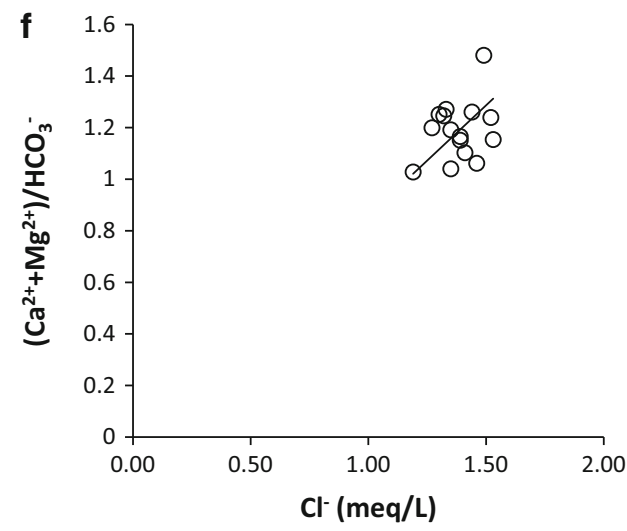

1992). Bicarbonate ion was reported as most dominant anion in both the wetlands (Table 1). The carbonate ion availability in water samples was $\sim 80 \%$ in the Kawar-Tal and $63 \%$ in Kusheshwar-Asthan out of total anions (Table 1).

\section{Hydrogeochemical evaluation}

The geochemical variations in the ionic concentration in the water samples can be easily understood when they are plotted on $X-Y$ cross-plots (Guler et al. 2002). Generally, in arid climates, chemical weathering is limited and the ionic composition of lake water is determined by the occasional precipitation (Nikanorov and Brazhnikova 1989). Low levels of solutes in both wetlands are thought to be influenced by uptake of solute by sediment and solute loss through underground seepage (Darling et al. 1990).

Most of the samples of both wetlands have a $\mathrm{Na}^{+} / \mathrm{Cl}^{-}$ molar ratio around 1 , indicating straight evaporative concentration with no ion-exchange process in study area (Figs. 2a, 3a). The graph between $\left(\mathrm{Ca}^{2+}+\mathrm{Mg}^{2+}\right)$ and $\left(\mathrm{SO}_{4}{ }^{2-}+\mathrm{HCO}_{3}{ }^{-}\right)$follows a nearly $1: 1$ line in both wetlands (Figs. 2b, 3b). These linear relationships between these ions would be expected with evaporative 
concentration. The graph of $\mathrm{TZ}+$ (total cation) versus $\left(\mathrm{Ca}^{2+}+\mathrm{Mg}^{2+}\right)$ shows most of the samples very close to theoretical line (1:1) indicate weathering of rock minerals that are dominant in both wetlands (Figs. 2c, 3c). The graph of $\mathrm{Na}^{+}$versus $\mathrm{NO}_{3}{ }^{-}$shows few water samples scattered and falling away from theoretical line (1:1), possibly indicating the effects of anthropogenic activities. The source of $\mathrm{Ca}^{2+}$ and $\mathrm{Mg}^{2+}$ ions in wetlands water can be deduced from the meq $\left(\mathrm{Ca}^{2+}+\mathrm{Mg}^{2+}\right) / \mathrm{meq}\left(\mathrm{HCO}_{3}{ }^{-}\right)$ ratio. If calcium and magnesium originate solely from dissolution of carbonate in the aquifer from the weathering of accessory pyroxene and amphibole minerals, the ratio would be about 0.5 . The graph between meq $\left(\mathrm{Ca}^{2+}+\right.$ $\left.\mathrm{Mg}^{2+}\right) / \mathrm{meq}\left(\mathrm{HCO}_{3}{ }^{-}\right)$and meqCl${ }^{-}$indicates contribution of anthropogenic input in both wetlands (Figs. 2f, 3f). The graph between $\left(\mathrm{SO}_{4}{ }^{2-}+\mathrm{Cl}^{-}\right)$and $\left(\mathrm{Na}^{+}+\mathrm{K}^{+}\right)$in KawarTal water samples is scattered, indicating some other source input along with natural weathering process (Fig. 2e). The graph between $\left(\mathrm{SO}_{4}{ }^{2-}+\mathrm{Cl}^{-}\right)$and $\left(\mathrm{Na}^{+}+\mathrm{K}^{+}\right)$in Kusheshwar-Asthan shows most of water samples falling close to the theoretical line and very few away from line, indicating natural weathering is the dominant process (Fig. 3e). Potassium contribution to the total cations was low in both wetlands $\sim 2.57 \%$ (Kawar-Tal) and $\sim 3.49 \%$ (Kusheshwar-Asthan) (Table 1). Evaporation plays a greater role in the concentration of potassium in lake waters; its resistance to weathering and its use in the formation of clay minerals cause the concentration of the element to be much lower than that of sodium (Nelson 2014). A significant amount of $\mathrm{CaCO}_{3}$ was reported in wetlands water, but it is one of the least soluble compounds in water. However, in weak acidic condition, $\mathrm{CaCO}_{3}$ can be converted to soluble $\mathrm{CaHCO}_{3}$. In this study, $\mathrm{Ca}^{2+}$ comprises about 56\% (Kawar-Tal) and 52\% (KusheshwarAsthan) of the total cations (Table 1).

\section{Statistical analysis}

Numerical analysis of hydrogeochemical data has been attempted to determine the geochemical factors that influence the chemical evolution of water (Lawrence and Upchurch 1982). A three-step approach was used to assess the data for both wetlands. The steps used were: the use of a univariate statistical analysis (analysis of individual chemical parameters); characterization of major ion concentrations using traditional geochemical plotting tools; and multivariate analysis (principal component analysis and cluster analysis). Multivariate statistics have been widely applied in the earth and environmental sciences (Schuenemeyer and Drew 2011). Multivariate methods involve the simultaneous analysis of multiple variables rather than an examination of commonalities as well as difference between large data sets. The major objectives of this evaluation were to delineate the study areas based on chemical signature and to identify the variables (chemical parameters) that best explain the underlying difference. The concentrations of major ions in respective areas were depicted using Piper (trilinear) and Stiff diagrams.

\section{Correlation matrix}

The correlation matrices for water samples collected from Kawar-Tal and Kusheshwar-Asthan are shown in Tables 2 and 3, respectively. In the Kawar-Tal water samples, $\mathrm{Ca}^{2+}$ ion shows strong correlations with $\mathrm{Mg}^{2+}(0.96)$ and $\mathrm{HCO}_{3}{ }^{-}(0.85)$ ions, suggesting a common source of origin (Table 2). Calcium ion also shows good correlations with EC (0.96) and TDS (0.96). Similarly, $\mathrm{Mg}^{2+}$ ions show good correlations with EC (0.90) and TDS (0.90); $\mathrm{HCO}_{3}{ }^{-}$ ions show good correlations with EC (0.81) and TDS (0.80), indicating that $\mathrm{Ca}^{2+}, \mathrm{Mg}^{2+}$ and $\mathrm{HCO}_{3}{ }^{-}$ions are the major contributors to the EC and TDS content of the water. Good relationships between these ions also indicate natural weathering processes occur in situ in the Kawar-Tal wetland. Potassium ions show significant correlations with $\mathrm{Mg}^{2+}$ (0.76), $\mathrm{Ca}^{2+}(0.68)$, EC (0.61) and TDS (0.61), indicating $\mathrm{K}^{+}$ions contribute significantly to the hydrochemistry of the wetlands. Nitrate ions show significant correlations with $\mathrm{Ca}^{2+}(0.45), \mathrm{Mg}^{2+}(0.53)$ and $\mathrm{K}^{+}(0.44)$ ions, indicating the possibility that nitrate in water may be from run-off containing fertilizer during the monsoon period from agriculture land (Table 2). The low nitrate was observed may be due to active denitrification in the KawarTal wetland sediments. The other ions $\mathrm{Na}^{+}, \mathrm{Cl}^{-}, \mathrm{SO}_{4}{ }^{2-}$, $\mathrm{PO}_{4}{ }^{3-}$ and $\mathrm{F}^{-}$do not show any significant correlation among each other or with other ions (Table 2). In Kusheshwar-Asthan water samples, $\mathrm{Ca}^{2+}$ shows a significant correlation with $\mathrm{Mg}^{2+}(0.79)$, suggesting that there is a common mineral source of these ions in water (Table 3 ). Calcium ion also shows average correlations with $\mathrm{HCO}_{3}{ }^{-}$ (0.35) and $\mathrm{Cl}^{-}(0.34)$ ion, indicating equal contributions of natural weathering and other source of these ions in water (Table 3). Sodium ion shows a very good correlation with $\mathrm{F}^{-}(0.76)$ ions and average correlation with $\mathrm{NO}_{3}{ }^{-}(0.35)$ ions, indicating possibility of anthropogenic input in Kusheshwar-Asthan water samples (Table 3). EC shows average correlation with $\mathrm{K}^{+}(0.41), \mathrm{Mg}^{2+}(0.32)$ and $\mathrm{SO}_{4}{ }^{2-}(0.27)$ (Table 3).

\section{DUROV diagram}

According to DUROV diagram of water sample of the study areas, the concentration of $\mathrm{Ca}^{2+}, \mathrm{Mg}^{2+}$ and $\mathrm{HCO}_{3}{ }^{-}$ ions mainly influences water quality (Fig. 4). It indicates dominance of natural weathering in both wetlands, while lesser effect of $\mathrm{Na}^{+}, \mathrm{Mg}^{2+}, \mathrm{Cl}^{-}$and $\mathrm{SO}_{4}{ }^{2-}$ ions is 
Table 3 Correlation matrix (Kusheshwar-Asthan)

\begin{tabular}{|c|c|c|c|c|c|c|c|c|c|c|c|c|c|}
\hline & $\mathrm{pH}$ & $\mathrm{EC}$ & TDS & $\mathrm{Ca}$ & $\mathrm{Mg}$ & $\mathrm{Na}$ & $\mathrm{K}$ & $\mathrm{Cl}^{-}$ & $\mathrm{HCO}_{3}{ }^{-}$ & $\mathrm{SO}_{4}^{2-}$ & $\mathrm{NO}_{3}^{-}$ & $\mathrm{F}^{-}$ & $\mathrm{PO}_{4}{ }^{3-}$ \\
\hline $\mathrm{pH}$ & 1 & & & & & & & & & & & & \\
\hline $\mathrm{EC}$ & -0.09 & 1 & & & & & & & & & & & \\
\hline TDS & -0.2 & 0.97 & 1 & & & & & & & & & & \\
\hline $\mathrm{Ca}$ & -0.12 & 0.03 & 0.07 & 1 & & & & & & & & & \\
\hline $\mathrm{Mg}$ & -0.13 & 0.32 & 0.37 & 0.79 & 1 & & & & & & & & \\
\hline $\mathrm{Na}$ & -0.21 & -0.31 & -0.25 & -0.12 & 0.27 & 1 & & & & & & & \\
\hline $\mathrm{K}$ & -0.03 & 0.41 & 0.44 & -0.15 & 0.22 & 0.22 & 1 & & & & & & \\
\hline $\mathrm{Cl}^{-}$ & -0.38 & 0 & 0.01 & 0.34 & 0.1 & -0.23 & 0.06 & 1 & & & & & \\
\hline $\mathrm{HCO}_{3}{ }^{-}$ & -0.01 & -0.22 & -0.15 & 0.35 & 0.39 & 0.22 & 0.19 & -0.08 & 1 & & & & \\
\hline $\mathrm{SO}_{4}^{2-}$ & -0.48 & 0.27 & 0.34 & 0.12 & 0.12 & -0.19 & -0.02 & -0.2 & 0.02 & 1 & & & \\
\hline $\mathrm{NO}_{3}^{-}$ & -0.58 & 0.02 & 0.11 & 0.13 & 0.2 & 0.35 & 0.17 & -0.09 & 0.39 & 0.52 & 1 & & \\
\hline $\mathrm{F}^{-}$ & 0.01 & -0.49 & -0.44 & -0.14 & 0.05 & 0.76 & 0.08 & -0.21 & -0.06 & -0.38 & 0.15 & 1 & \\
\hline $\mathrm{PO}_{4}{ }^{3-}$ & -0.09 & -0.17 & -0.07 & 0.14 & 0.14 & 0.04 & 0.22 & 0.02 & 0.3 & -0.09 & -0.22 & 0.17 & 1 \\
\hline
\end{tabular}

observed (Fig. 4). A very small variation was observed in both the wetlands due to similar subtropical climate and geology. Geologically, both wetlands are similar to small variation of few minerals.

\section{Piper diagram}

Piper diagrams are often used to classify water types. Each data point on a Piper diagram reflects relative molar proportions of major ions, rather than their absolute concentrations. Water samples from both wetlands have a water composition that is dominated by the cations $\mathrm{Ca}^{2+}$ and $\mathrm{Mg}^{2+}$ and by the anion $\mathrm{HCO}_{3}{ }^{-}$(Fig. 5).

\section{Mechanisms controlling water chemistry (Gibbs diagram)}

The source of major ions in water can be defined by plotting the samples according to the variations in weight ratios of $\left(\mathrm{Na}^{+}+\mathrm{K}^{+}\right) /\left(\mathrm{Na}^{+}+\mathrm{K}^{+}+\mathrm{Ca}^{2+}\right)$ as function of TDS (Gibbs 1970). Rock weathering appears to be the principal mechanism controlling the ion chemistry of both wetlands (Fig. 6). In both wetlands, sulphate/chloride ratio is below 0.50 [ranging from 0.24 to 0.30 (Kawar-Tal) and 0.36 to 0.47 (Kusheshwar-Asthan)], suggesting that there is a limited anthropogenic input of sulphur and limited in situ leaching of this element (Table 4). In KusheshwarAsthan, the $\mathrm{Na}^{+} / \mathrm{Cl}^{-}$ratio is 0.85 , while in Kawar-Tal it is 1.28 (Table 4), indicating some additional sodium source must be there other than precipitation. The calcium/bicarbonate ratio is less than 1.00 at both wetlands, suggesting that these ions were sourced by microbial respiration of organic carbon in sediments (Table 4). The bicarbonate/total anion ratio is less than 1.00 in both wetlands, suggesting that there is only a limited anthropogenic influence on both the study sites. Nitrate/total anion ratio is $0.1-0.2$ in Kawar-Tal and 0.01-0.02 in Kusheshwar-Asthan, indicating most of nitrate is consumed by denitrification in both wetlands (Table 4). The fluoride/magnesium ratio is $0.01-0.03$ in Kawar-Tal and 0.01-0.02 in Kusheshwar-Asthan, indicating fluoride is devoid of natural weathering (Table 4).

\section{Stability diagrams}

Mineral stability offers an opportunity to study the equilibrium between silicate minerals and natural waters. The principle behind such an approach is that water derives its composition from the parent rock in the weathering region and suspended sediments owe their mineralogical composition partly to the parent rock and partly to the chemical reaction of rock and water (Garrel and Christ 1966). Thus by studying the water chemistry, stable mineral assemblages can theoretically be predicted. In the current study, an attempt has been made to apply this approach to the studied wetland (Figs. 7, 8).

The plot of the silicate diagram of Kawar-Tal waters is mainly in the range of stability field of gibbsite with a few points in the kaolinite range (Fig. 7). For water samples from the Kusheshwar-Asthan, the silicate stability diagrams show most of the samples in kaolinite range (Fig. 8). This implies that hydrochemistry of water in KusheshwarAsthan is favouring kaolinite formation and in Kawar-Tal favouring kaolinite-gibbsite formation. This was also justified by dominance of clay minerals (18-24\%) in surface sediment of both wetlands (Table 5). 
a
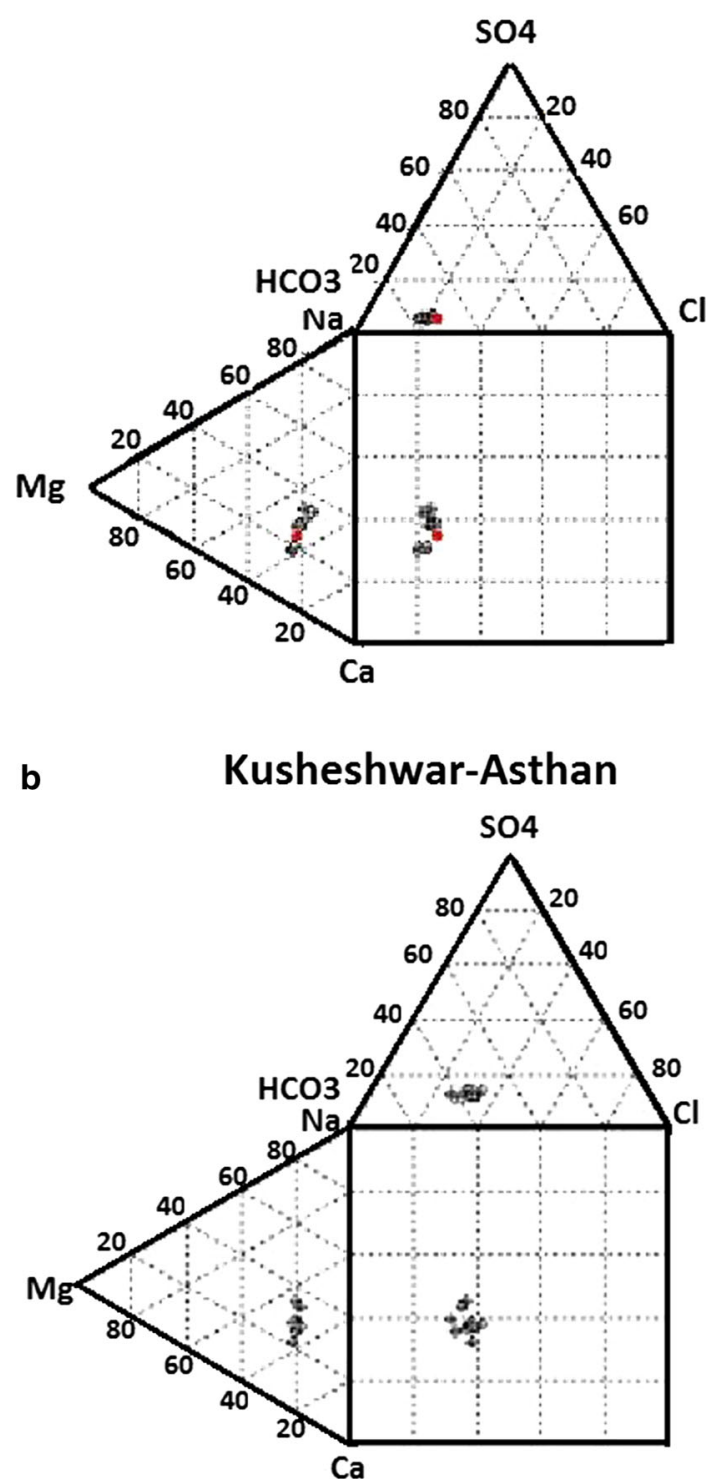

Fig. 4 DUROV diagram of Kawar-Tal and Kusheshwar-Asthan wetlands

\section{Heavy metal analysis}

Only a limited number of chemical analyses were carried out in this study for the metals $\mathrm{Fe}, \mathrm{Mn}, \mathrm{Ni}, \mathrm{Cd}, \mathrm{Cu}, \mathrm{Pb}$ and Zn. Kawar-Tal lake water contains Fe $(\sim 0.06 \mathrm{mg} / \mathrm{L}), \mathrm{Mn}$ ( $\sim 0.03 \mathrm{mg} / \mathrm{L}), \mathrm{Ni}(\sim 0.06 \mathrm{mg} / \mathrm{L}), \mathrm{Cu}(\sim 0.002 \mathrm{mg} / \mathrm{L}), \mathrm{Zn}$ $(\sim 0.02 \mathrm{mg} / \mathrm{L}), \quad \mathrm{Cd} \quad(\sim 0.02 \mathrm{mg} / \mathrm{L}), \quad \mathrm{Pb}(\sim 0.46 \mathrm{mg} / \mathrm{L})$, while Kusheshwar-Asthan lake water contains $\mathrm{Fe}$ ( $\sim 0.65 \mathrm{mg} / \mathrm{L}), \mathrm{Mn}(\sim 0.04 \mathrm{mg} / \mathrm{L}), \mathrm{Ni}(\sim 0.05 \mathrm{mg} / \mathrm{L}), \mathrm{Cu}$ ( $\sim 0.004 \mathrm{mg} / \mathrm{L}), \mathrm{Zn}(\sim 0.02 \mathrm{mg} / \mathrm{L}), \mathrm{Cd}(\sim 0.02 \mathrm{mg} / \mathrm{L})$ and $\mathrm{Pb}(\sim 0.49 \mathrm{mg} / \mathrm{L})$ (Table 1). High iron concentration in Kusheshwar-Asthan may be due to local input or probably associated with local microbial reductive dissolution of iron oxide in wetland sediments. Lead concentrations are a
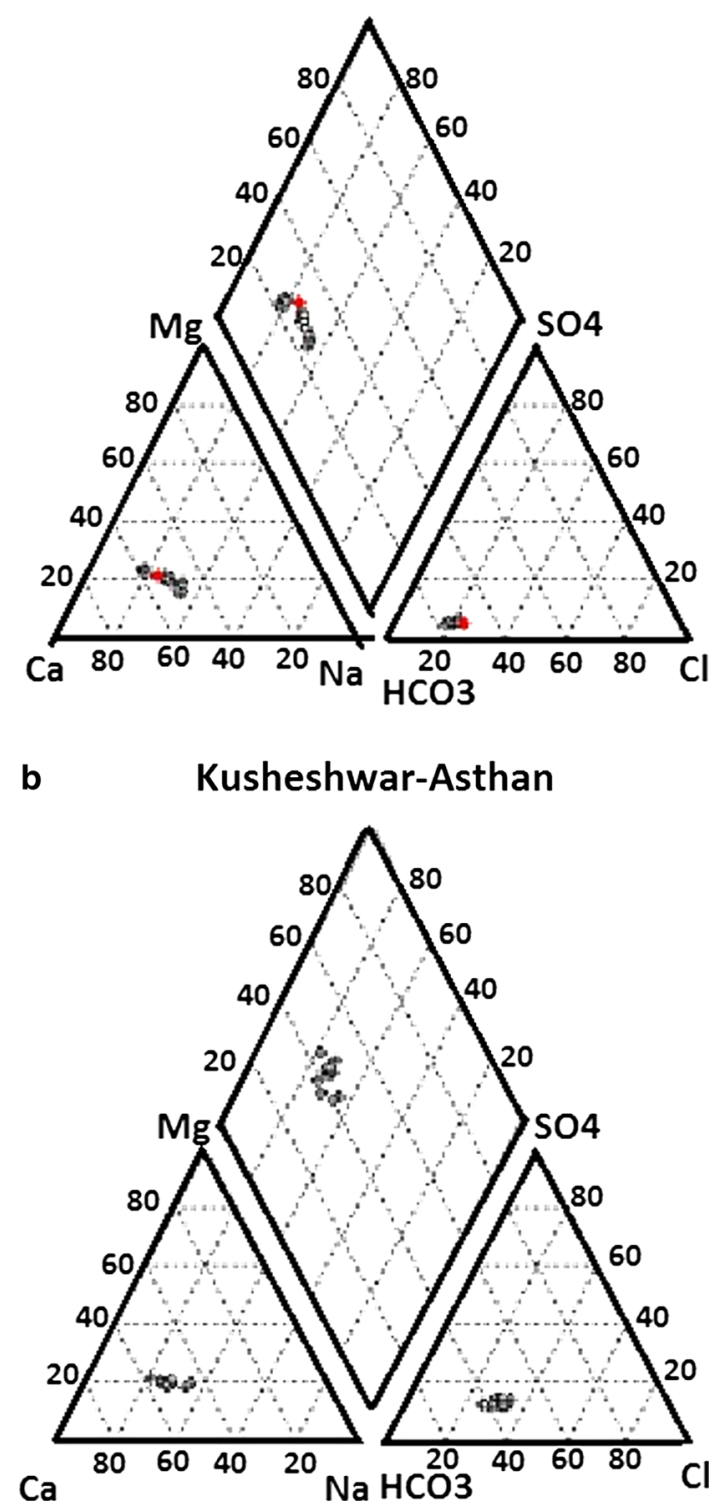

Fig. 5 Piper diagram of Kawar-Tal and Kusheshwar-Asthan wetlands

significant in both wetlands, maybe due to some local anthropogenic input. Other heavy metals concentrations are under permissible limit of World Health Organization (2006).

\section{Mineralogy of surface sediments}

The mineralogical study was carried out by X-ray Diffractometer (XRD). The results indicate that the major mineral present in all the samples of both wetlands surface sediment is quartz (Table 5). The most abundant minerals in Kawar-Tal sediments (in order of decreasing abundance) are quartz (34.78-38.02\%), chlorite (10.62-12.13\%), 
Table 4 Summary of various statistical relations between chemical parameters of KawarTal and Kusheshwar-Asthan

\begin{tabular}{|c|c|c|c|c|c|c|c|c|}
\hline \multirow{2}{*}{$\begin{array}{l}\text { Chemical parameter various } \\
\text { relation }\end{array}$} & \multicolumn{4}{|c|}{ Kawar-Tal } & \multicolumn{4}{|c|}{ Kusheshwar-Asthan } \\
\hline & Min. & Max. & Avg. & SD & Min. & Max. & Avg. & SD \\
\hline TDS/EC & 0.66 & 0.67 & 0.66 & 0.005 & 0.66 & 0.67 & 0.66 & 0.006 \\
\hline $\mathrm{SO}_{4}{ }^{2-} / \mathrm{Cl}^{-}$ & 0.24 & 0.3 & 0.27 & 0.02 & 0.36 & 0.47 & 0.42 & 0.04 \\
\hline $\mathrm{Na}^{+} / \mathrm{Cl}^{-}$ & 0.96 & 1.75 & 1.28 & 0.22 & 0.69 & 1.23 & 0.85 & 0.16 \\
\hline $\mathrm{Ca}^{2+} / \mathrm{HCO}_{3}^{-}$ & 0.6 & 0.9 & 0.75 & 0.1 & 0.73 & 1.08 & 0.85 & 0.09 \\
\hline $\mathrm{Ca}^{2+}+\mathrm{Mg}^{2+}$ & 2.36 & 4.17 & 3.14 & 0.68 & 2.76 & 3.12 & 2.98 & 0.25 \\
\hline $\mathrm{Na}^{+}+\mathrm{K}^{+}$ & 1.61 & 2.15 & 1.94 & 0.18 & 1.1 & 1.68 & 1.24 & 0.18 \\
\hline$\left(\mathrm{Ca}^{2+}+\mathrm{Mg}^{2+)} /\left(\mathrm{Na}^{+}+\mathrm{K}^{+}\right)\right.$ & 1.85 & 4.28 & 2.89 & 0.9 & 1.76 & 3.42 & 2.46 & 0.38 \\
\hline $\mathrm{HCO}_{3}{ }^{-} / \mathrm{TA}^{-}$ & 0.7 & 0.77 & 0.73 & 0.02 & 0.54 & 0.62 & 0.56 & 0.03 \\
\hline $\mathrm{NO}_{3}{ }^{-} / \mathrm{TA}^{-}$ & 0.1 & 0.2 & 0.11 & 0.003 & 0.01 & 0.02 & 0.02 & 0.003 \\
\hline $\mathrm{F}^{-} / \mathrm{Mg}^{2+}$ & 0.01 & 0.03 & 0.015 & 0.01 & 0.01 & 0.02 & 0.01 & 0.005 \\
\hline $\mathrm{Fe}^{2+} / \mathrm{SO}_{4}{ }^{2-}$ & 0 & 0.03 & 0.01 & 0.01 & 0.02 & 0.07 & 0.04 & 0.01 \\
\hline
\end{tabular}

min. minimum, max. maximum, $A v g$. average, $S D$ standard deviation muscovite $(6.43-7.64 \%)$, orthoclase (11.99-13.02\%), calcite $(6.94-8.13 \%)$, illite $(4.19-5.69 \%)$ and other clay minerals (18.25-22.88\%) (Table 5). The most abundant minerals in the Kusheshwar-Asthan surface sediments are quartz (33.43-37.13\%), chlorite (8.12-11.43\%), muscovite $(12.11-14.07 \%)$, albite $(5.12-7.11 \%)$, biotite (12.11-14.07\%) and other clay minerals (20.11-24.11\%) (Table 5). Orthoclase, calcite and illite minerals are only reported in Kawar-Tal wetland core sediments. Similarly, albite and biotite minerals are only reported in Kusheshwar-Asthan core sediment and not in Kawar-Tal core sediment (Table 5).

High silica concentrations that were measured in surface sediments of the Kawar-Tal $(\sim 35 \%)$ and KusheshwarAsthan $(32.88 \%$ ) may be due to dominance of quartz in surface sediment (Table 6). At both sites, silica concentrations are higher than the Indian river average, i.e. $24.5 \%$. The significant aluminium concentration was observed in surface sediment of the Kawar-Tal $(\sim 6.63 \%)$ and Kusheshwar-Asthan (4.8\%) (Table 6). At both the places, concentration of aluminium is less than the world average aluminium concentration of river, i.e. $9.40 \%$ in surface sediment. This indicates that most of sediments are derived from quartz-rich components as orthoquartzites in the area. The low aluminium content in the sediments also indicates low amount of clay minerals and hence dominance of quartz in the sediments.

\section{Carbon/nitrogen ratio}

In the Kawar-Tal surface sediments, the $\mathrm{C} / \mathrm{N}$ ratio is higher than that in the Kusheshwar-Asthan surface sediments. The range of $\mathrm{C} / \mathrm{N}$ ratio is $4.80-5.92$ in Kawar-Tal and 2.43-5.40 in Kusheshwar-Asthan (Table 6). According to the surface sediment analysis in Kawar-Tal, percentage of TC ranges between 2.40 and $3.49 \%$, with mean value $3.00 \%$; in Kusheshwar-Asthan, TC ranges between 1.53 and $3.25 \%$, with mean value $2.38 \%$ (Table 6). The TS in the sediments ranges between 0.0003 and $0.0014 \%$, with value almost similar in both wetlands. Sample analysis data show that IC percentage in KawarTal ranges between 0.42 and $1.31 \%$, with mean value $0.90 \%$. In Kusheshwar-Asthan, IC ranges between 0.39 and $0.72 \%$, with a mean value $0.55 \%$. At both sites, IS is available in very less quantity $(0.0001-0.0006 \%)$. The OC and OS are present in more quantity than IC and IS, in both the study areas (Table 6). The OC ranges between 1.73 and $2.29 \%$, with mean value $2.1 \%$ in Kawar-Tal and $1.14-2.53 \%$, with mean value $1.84 \%$ in KusheshwarAsthan. OS ranges between 0.0002 and $0.0009 \%$ in both the places (Table 6). The nitrogen percentage is slightly more in Kusheshwar-Asthan than in Kawar-Tal. In Kawar-Tal sediments, nitrogen varies from 0.50 to $0.59 \%$, with mean value $0.55 \%$, and in Kusheshwar-Asthan, range is $0.57-0.67 \%$, with mean value $0.62 \%$. Phosphate percentage is more in Kawar-Tal $(\sim 0.96 \%)$ than in Kusheshwar-Asthan $(\sim 0.64 \%)$.

\section{Sediment analysis}

Grain size is the most fundamental property of sediment particles affecting their environment, transport, deposition and biodiversity. Grain size analysis helps to understand the sediment provenance, transport history and depositional conditions (Folk and Ward 1957; Friedman 1979; Bui et al. 1990). The grains distribution in the surface sediment of both the wetlands Kawar-Tal and Kusheshwar-Asthan is poorly sorted. Statistical calculation was made in laboratory by the standard method (Krumbein and Pettijohn 1958; Lindholm 1987). The Kawar-Tal surface sediment 
Fig. 6 Gibbs diagram (mechanism controlling water chemistry) (Kawar-Tal and Kusheshwar-Asthan)
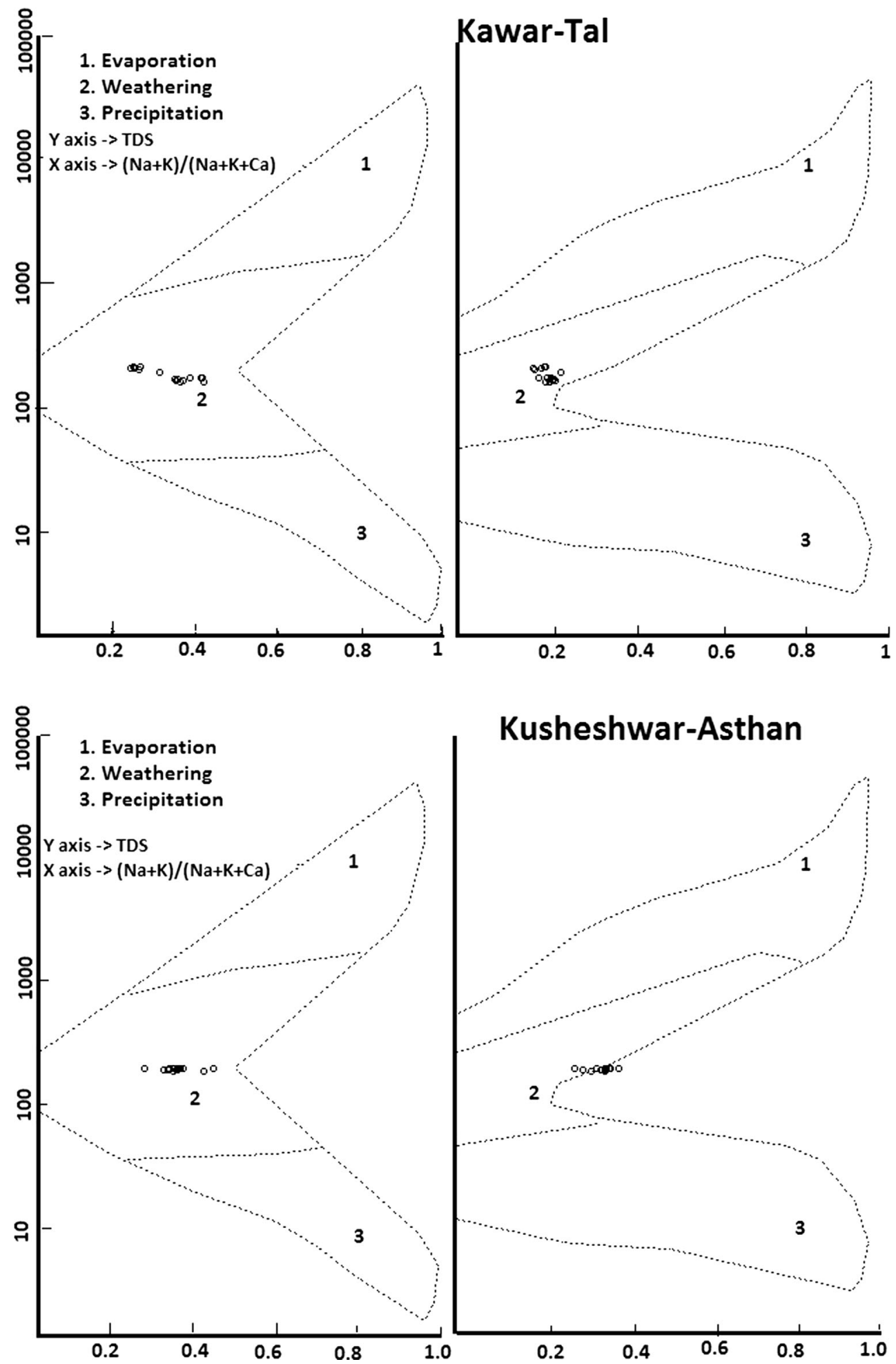

Kusheshwar-Asthan

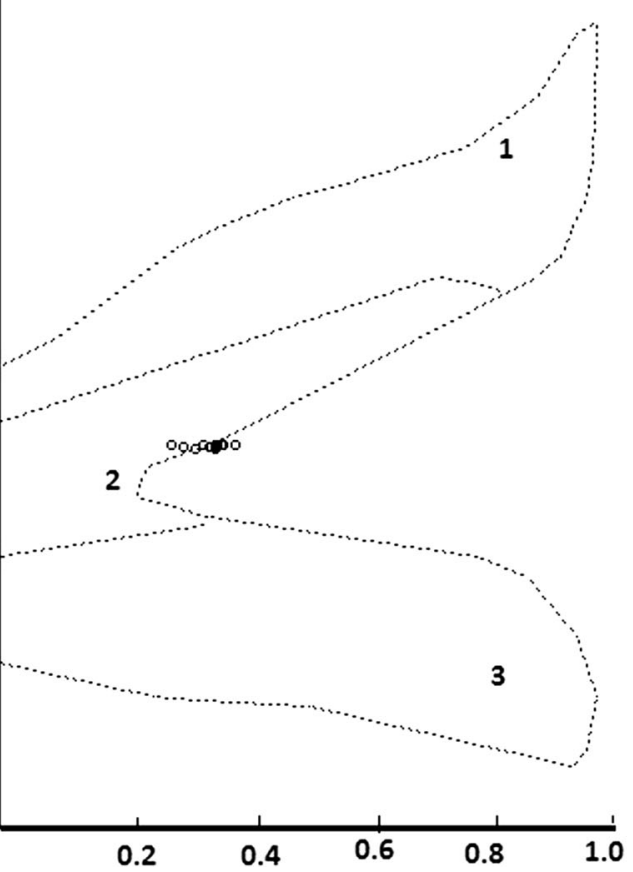

grains are moderately sorted and symmetrically skewed, and sediments grains are very platykurtic (Table 7). In Kusheshwar-Asthan, sediments are moderately well sorted, coarse-skewed, and sediment grains are very platykurtic (Table 7).

\section{Conclusion}

The distribution pattern of major cations and anions in water samples of the both wetlands was as follows: $\mathrm{Ca}^{2+}>\mathrm{Na}^{+}>\mathrm{Mg}^{2+}>\mathrm{K}^{+}$ and 

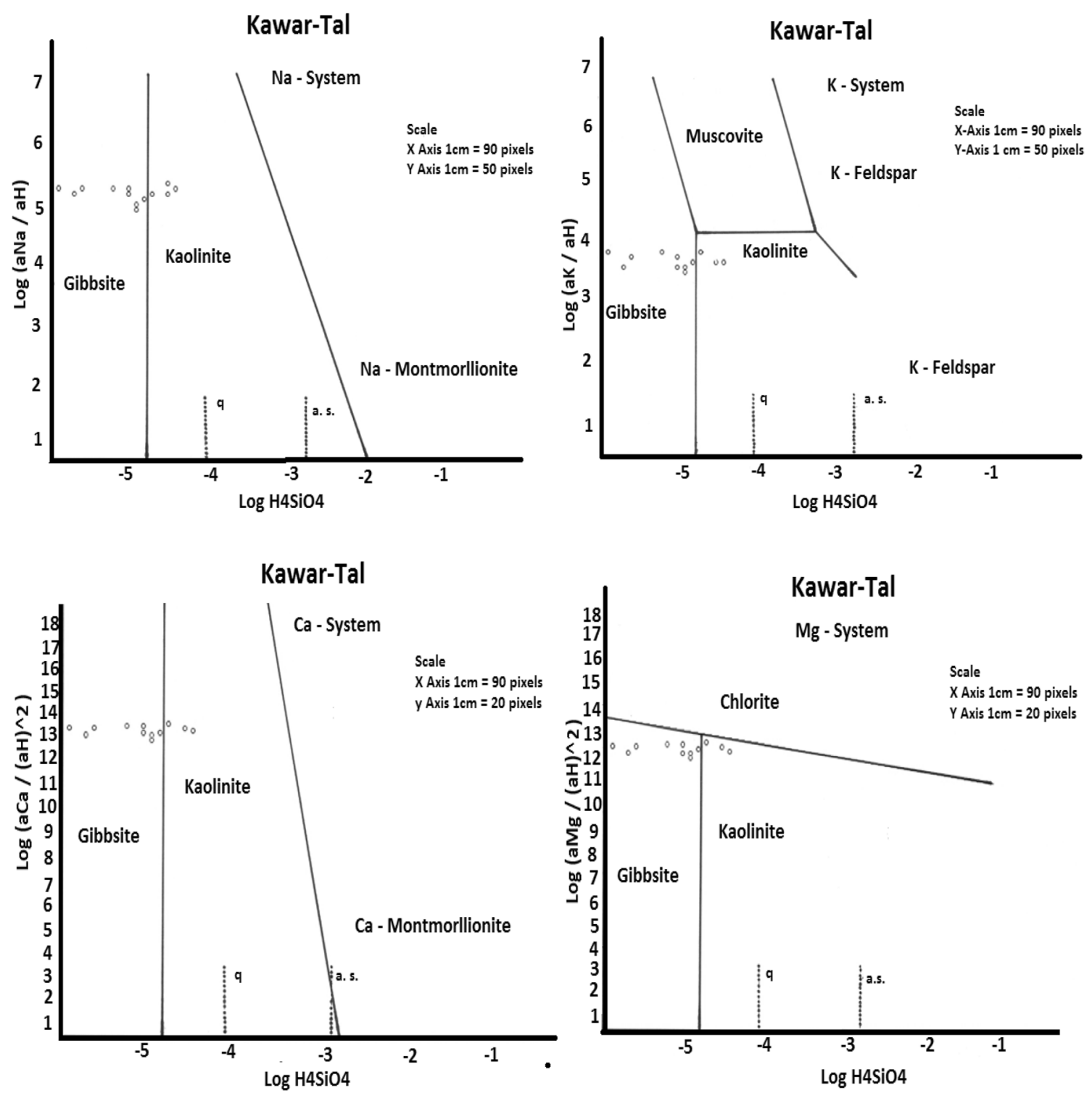

Fig. 7 Stability diagram of water samples (Kawar-Tal wetland)

$\mathrm{HCO}_{3}{ }^{-}>\mathrm{Cl}^{-}>\mathrm{SO}_{4}{ }^{2-}>\mathrm{NO}_{3}{ }^{-}>\mathrm{F}^{-}=\mathrm{PO}_{4}{ }^{3-}$. Most of the water samples showed good charge balance with $\pm 5 \%$ error. The classification of hydrochemical facies of both wetlands shows dominance of chemical facies $\mathrm{Ca}^{2+}+$ $\mathrm{Mg}^{2+}, \mathrm{SO}_{4}{ }^{2-}-\mathrm{Cl}^{-}$and $\mathrm{HCO}_{3}{ }^{-}-\mathrm{CO}_{3}{ }^{2-}$ (Fig. 9). The analysed data show $\mathrm{Ca}^{2+}$ ion and $\mathrm{HCO}_{3}{ }^{-}$ion are the most dominant ions in both the wetlands water. Most of the samples of both wetlands have a $\mathrm{Na}^{+} / \mathrm{Cl}^{-}$ratio around 1 , indicating straight evaporative concentration with no ionexchange process in study area. The graph between $\left(\mathrm{Ca}^{2+}+\mathrm{Mg}^{2+}\right)$ and $\left(\mathrm{SO}_{4}{ }^{2-}+\mathrm{HCO}_{3}{ }^{-}\right)$was featured a nearly 1:1 line in both wetlands, indicating evaporative concentration. The graph of $\mathrm{TZ}+$ (total cation) versus $\left(\mathrm{Ca}^{2+}+\mathrm{Mg}^{2+}\right)$ shows most of the samples very close to theoretical line (1:1) indicate weathering of rock minerals that are dominant in both wetlands. The graph of $\mathrm{Na}^{+}$ versus $\mathrm{NO}_{3}{ }^{-}$shows few water samples scattered and falling away from theoretical line (1:1), indicating interference of anthropogenic activities. The source of $\mathrm{Ca}$ and $\mathrm{Mg}$ in wetlands water can be deduced from the meq $\left(\mathrm{Ca}^{2+}+-\right.$ $\left.\mathrm{Mg}^{2+}\right) / \mathrm{meq}\left(\mathrm{HCO}_{3}{ }^{-}\right)$ratio. The graph between meq $\left(\mathrm{Ca}^{2+}+\mathrm{Mg}^{2+}\right) /$ meq $\left(\mathrm{HCO}_{3}{ }^{-}\right)$and meq $\mathrm{Cl}^{-}$indicates 

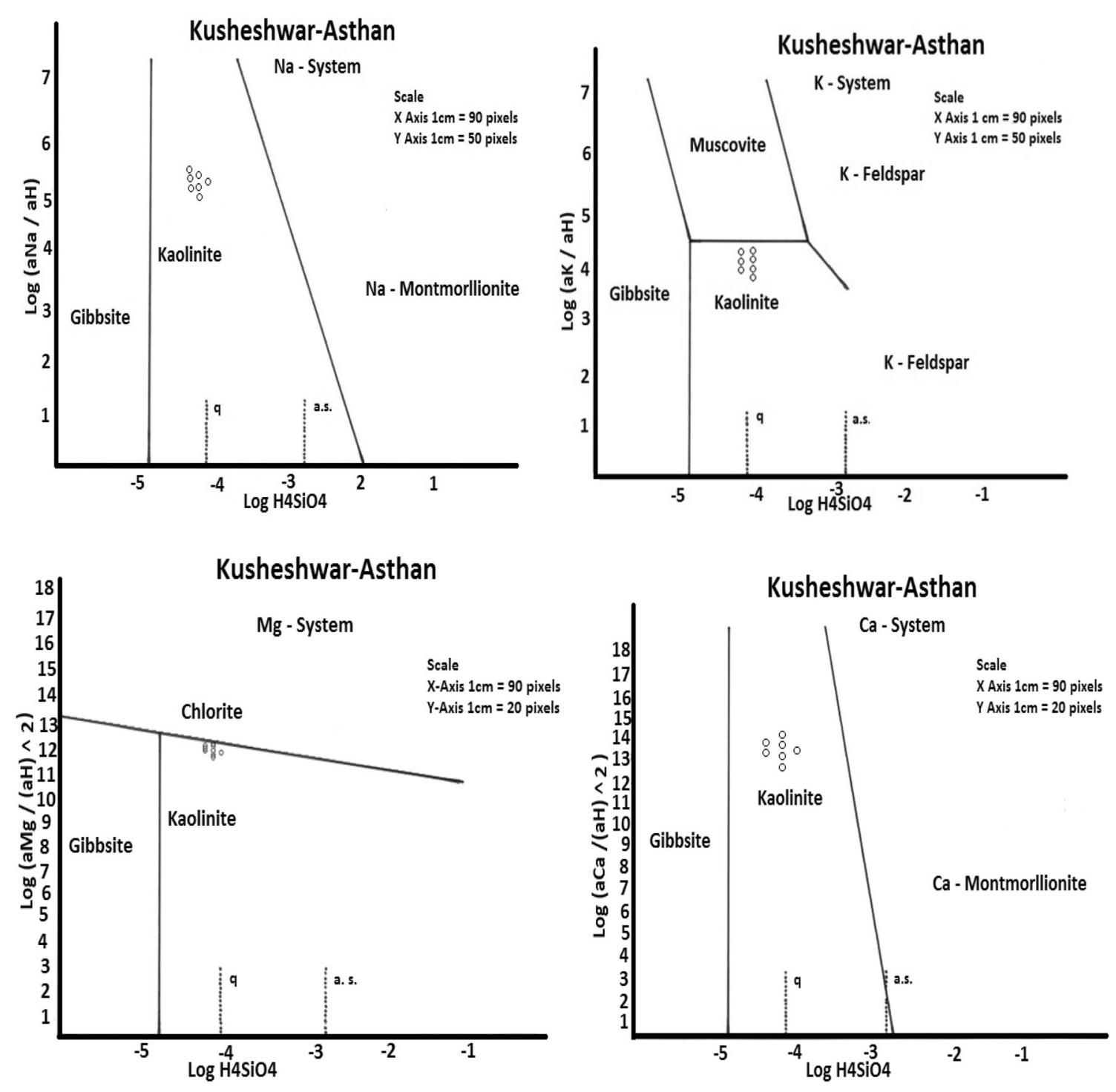

Fig. 8 Stability diagram of water samples (Kusheshwar-Asthan wetland)

dominance of weathering over anthropogenic inputs in both wetlands. The graph between $\left(\mathrm{SO}_{4}^{2-}+\mathrm{Cl}^{-}\right)$and $\left(\mathrm{Na}^{+}+\mathrm{K}^{+}\right)$in Kawar-Tal water samples is scattered, indicating some other source input along with natural weathering process. Rock weathering is the principle mechanism controlling the water chemistry of both wetlands. The stability diagram of Kawar-Tal wetland water indicates that water is in equilibrium with gibbsite and kaolinite, but in Kusheshwar-Asthan, it is in equilibrium with kaolinite. This indicates that the hydrogeochemistry of water in Kusheshwar-Asthan is favouring kaolinite formation and in Kawar-Tal favouring kaolinite-gibbsite formation. All the water samples of Kawar-Tal wetland are in "good" quality range (20-40\%) on the basis of percentage of sodium. Few samples (20\%) were even recorded in "excellent" quality range. But in Kusheshwar-Asthan, all the water samples are in "good" quality range only. Based on conductivity suggested, both the locations' water quality is in "good" range, i.e. 250 to $750 \mu \mathrm{S} / \mathrm{cm}$. The cationic composition indicates that water of both the wetlands is dominated by calcium ions. The anionic composition indicates that water of both the wetlands is dominated by bicarbonate ions.

Quartz ( $\sim 36 \%)$ and clay minerals $(\sim 21 \%)$ are the most dominant minerals in both wetlands. Total carbon concentrations at both the sites indicate that there is sufficient 
Table 5 Summary of statistics of mineral (\%) in sediment of Kawar-Tal and KusheshwarAsthan

\begin{tabular}{|c|c|c|c|c|c|c|c|c|}
\hline \multirow[t]{2}{*}{ Minerals (\%) } & \multicolumn{4}{|c|}{ Kawar-Tal } & \multicolumn{4}{|c|}{ Kusheshwar-Asthan } \\
\hline & Min. & Max. & Avg. & SD & Min. & Max. & Avg. & SD \\
\hline Quartz & 34.78 & 38.02 & 36.19 & 1.42 & 33.43 & 37.13 & 34.95 & 1.61 \\
\hline Chlorite & 10.62 & 12.13 & 11.45 & 0.71 & 8.12 & 11.43 & 9.69 & 1.41 \\
\hline Muscovite & 6.43 & 7.64 & 6.95 & 0.51 & 12.11 & 14.07 & 13.19 & 0.82 \\
\hline Orthoclase & 11.99 & 13.02 & 12.49 & 0.48 & NA & NA & NA & NA \\
\hline Calcite & 6.94 & 8.13 & 7.51 & 0.62 & NA & NA & NA & NA \\
\hline Illite & 4.19 & 5.69 & 4.89 & 0.63 & NA & NA & NA & NA \\
\hline Albite & NA & NA & NA & NA & 5.12 & 7.11 & 6.29 & 0.88 \\
\hline Biotite & NA & NA & NA & NA & 12.11 & 14.07 & 13.6 & 1.29 \\
\hline Other clay minerals & 18.25 & 22.88 & 20.53 & 2.01 & 20.11 & 24.11 & 22.52 & 2.1 \\
\hline
\end{tabular}

min. minimum, max. maximum, $A v g$. average, $S D$ standard deviation

Table 6 Summary of statistics of biogeochemical parameters (\%) in sediment of Kawar-Tal and Kusheshwar-Asthan

\begin{tabular}{|c|c|c|c|c|c|c|c|c|}
\hline \multirow{2}{*}{$\begin{array}{l}\text { Biogeochemical } \\
\text { parameter }(\%)\end{array}$} & \multicolumn{4}{|c|}{ Kawar-Tal } & \multicolumn{4}{|c|}{ Kusheshwar-Asthan } \\
\hline & Min. & Max. & Avg. & SD & Min. & Max. & Avg. & SD \\
\hline Total Carbon (TC) & 2.4 & 3.49 & 3 & 0.53 & 1.53 & 3.25 & 2.38 & 0.72 \\
\hline Inorganic Carbon (IC) & 0.42 & 1.31 & 0.9 & 0.42 & 0.39 & 0.72 & 0.55 & 0.14 \\
\hline Organic Carbon (OC) & 1.73 & 2.29 & 2.1 & 0.25 & 1.14 & 2.53 & 1.84 & 0.58 \\
\hline Total Sulphur (TS) & 0.0003 & 0.0014 & 0.0008 & 0.0005 & 0.0008 & 0.0013 & 0.001 & 0.0002 \\
\hline Organic Sulphur (OS) & 0.0002 & 0.0009 & 0.0005 & 0.0003 & 0.0007 & 0.0009 & 0.0008 & 0.0001 \\
\hline Inorganic Sulphur (IS) & 0.0001 & 0.0005 & 0.0003 & 0.0002 & 0.0001 & 0.0006 & 0.0003 & 0.0002 \\
\hline Nitrogen & 0.5 & 0.59 & 0.55 & 0.04 & 0.57 & 0.67 & 0.62 & 0.04 \\
\hline Phosphate & 0.84 & 1.12 & 0.96 & 0.12 & 0.61 & 0.67 & 0.64 & 0.03 \\
\hline Silicon & 34 & 36 & 35 & 0.91 & 31.5 & 34.5 & 32.88 & 1.38 \\
\hline Aluminium & 6.25 & 7 & 6.63 & 0.32 & 4.45 & 5.5 & 4.8 & 0.48 \\
\hline Carbon/Nitrogen $(\mathrm{C} / \mathrm{N})$ & 4.8 & 5.92 & 5.44 & 0.57 & 2.43 & 5.4 & 3.9 & 1.31 \\
\hline
\end{tabular}

min. minimum, max. maximum, Avg. average, $S D$ standard deviation

Table 7 Statistics of grain size by using graphical method

\begin{tabular}{|c|c|c|c|c|c|c|c|c|c|}
\hline \multicolumn{5}{|c|}{ Kawar-Tal } & \multicolumn{5}{|c|}{ Kusheshwar-Asthan } \\
\hline Station & Mean & $\mathrm{SD}$ & Skewness & Kurtosis & Station & Mean & SD & Skewness & Kurtosis \\
\hline TS1 & 0.1 & 1.56 & 0.25 & 1.15 & AS1 & 0.17 & 1.51 & 0.82 & 0.92 \\
\hline TS2 & 0.12 & 1.66 & 0.29 & 1.18 & AS2 & 0.15 & 1.48 & 0.71 & 0.91 \\
\hline TS3 & 0.12 & 1.71 & 0.3 & 1.19 & AS3 & 0.21 & 1.67 & 0.94 & 0.99 \\
\hline TS4 & 0.11 & 1.63 & 0.27 & 1.17 & AS4 & 0.19 & 1.61 & 0.9 & 0.97 \\
\hline
\end{tabular}

organic matter available to sustain biological activities. Sulphur was reported in significant concentration in both places. The presence of nutrients, i.e. nitrogen and phosphates, is in good amount in both the places showing ideal environment for vegetation and biological productivity. Silica concentrations in the sediment samples of both the places exceed the average for Indian rivers. Aluminium is present in lower concentrations than the world average for surface sediments at both sites. Kawar-Tal lake water contains $\mathrm{Fe}(\sim 0.06 \mathrm{mg} / \mathrm{L}), \mathrm{Mn}(\sim 0.03 \mathrm{mg} / \mathrm{L}), \mathrm{Ni}(\sim 0.06 \mathrm{mg} /$ $\mathrm{L}), \mathrm{Cu}(\sim 0.002 \mathrm{mg} / \mathrm{L}), \mathrm{Zn}(\sim 0.02 \mathrm{mg} / \mathrm{L}), \mathrm{Cd}(\sim 0.02 \mathrm{mg} /$ $\mathrm{L}), \mathrm{Pb}(\sim 0.46 \mathrm{mg} / \mathrm{L})$, while in Kusheshwar-Asthan water contains $\mathrm{Fe} \quad(\sim 0.65 \mathrm{mg} / \mathrm{L}), \quad \mathrm{Mn} \quad(\sim 0.04 \mathrm{mg} / \mathrm{L}), \quad \mathrm{Ni}$ ( $\sim 0.05 \mathrm{mg} / \mathrm{L}), \mathrm{Cu}(\sim 0.004 \mathrm{mg} / \mathrm{L}), \mathrm{Zn}(\sim 0.02 \mathrm{mg} / \mathrm{L}), \mathrm{Cd}$ ( $\sim 0.02 \mathrm{mg} / \mathrm{L})$ and $\mathrm{Pb}(\sim 0.49 \mathrm{mg} / \mathrm{L})$. The study indicates wetlands are rich in nutrients for biological activities and are 
Classification of Hydrogeochemical facies \& Environment

Reconstructed Diamond Field of Piper, Lawrence and Balasubramanian, $1994^{\circ}$

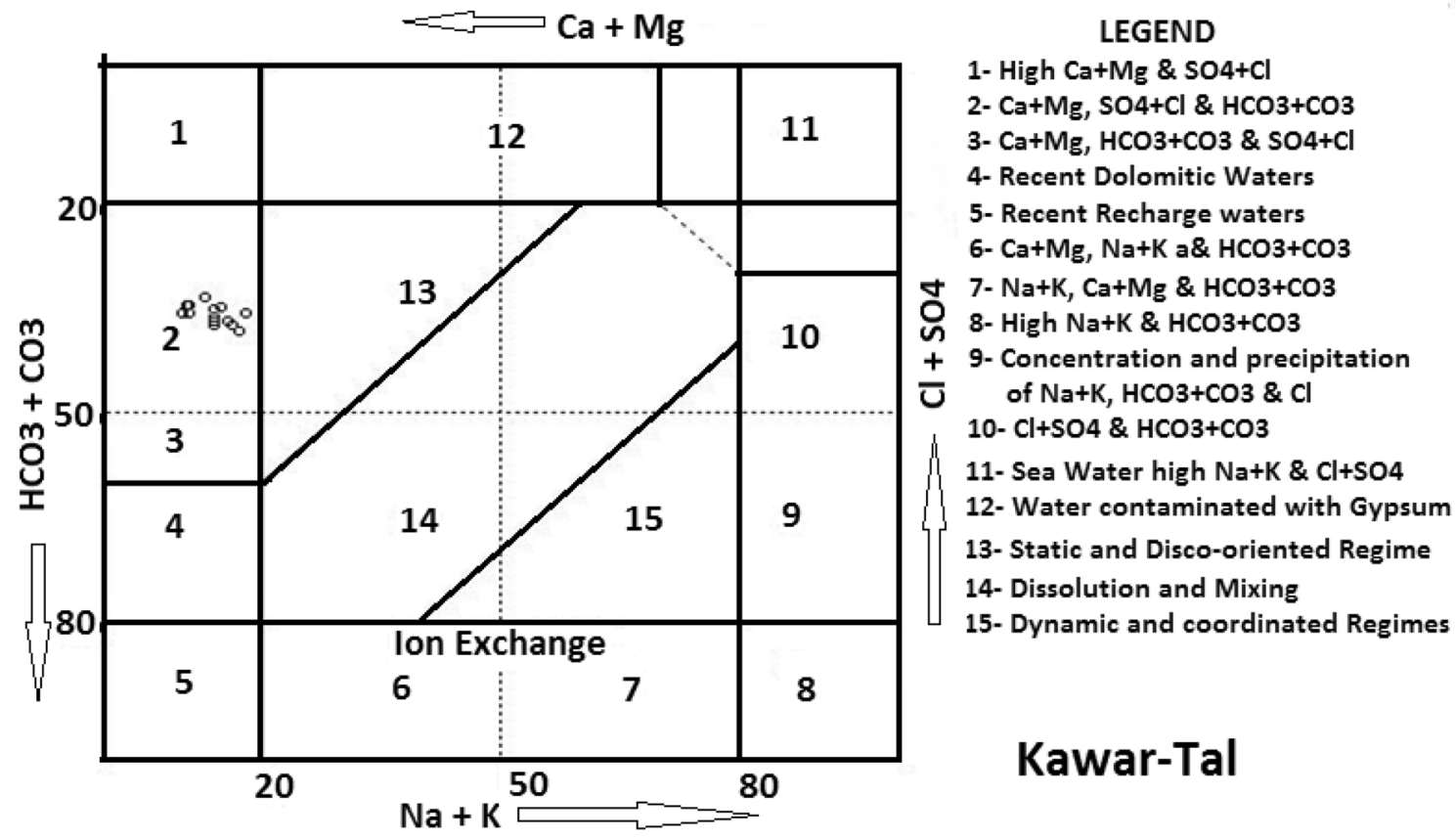

\section{Classification of Hydrogeochemical Facies \& Environment}

Reconstructed Diamond Field of Piper, Lawerence and Balasubramanian, 1994

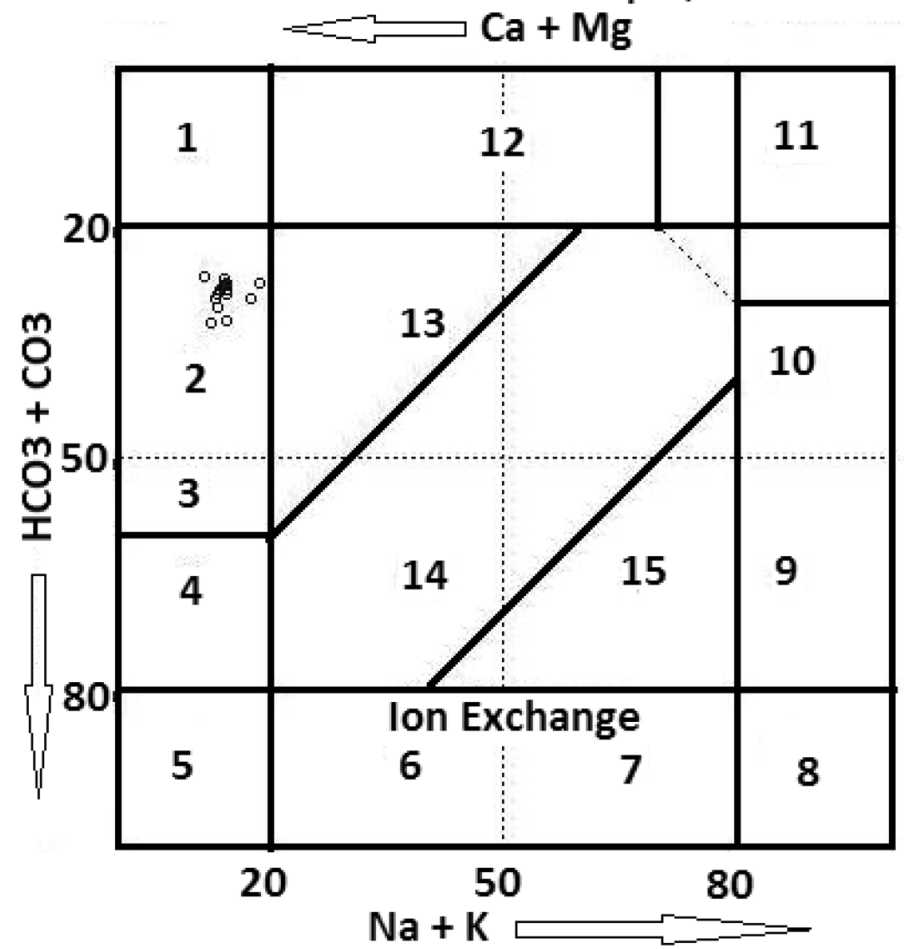

\section{LEGEND}

1- High Ca+Mg \& SO4+Cl

2- $\mathrm{Ca}+\mathrm{Mg}, \mathrm{SO} 4+\mathrm{Cl} \& \mathrm{HCO} 3+\mathrm{CO} 3$

3- $\mathrm{Ca}+\mathrm{Mg}, \mathrm{HCO} 3+\mathrm{CO} 3 \& \mathrm{SO} 4+\mathrm{Cl}$

4- Recent Dolomitic Waters

5- Recent Recharge Waters

6- $\mathrm{Ca}+\mathrm{Mg}, \mathrm{Na}+\mathrm{K} \& \mathrm{HCO} 3+\mathrm{CO} 3$

7- $\mathrm{Na}+\mathrm{K}, \mathrm{Ca}+\mathrm{Mg} \& \mathrm{HCO} 3+\mathrm{CO} 3$

8- High $\mathrm{Na}+\mathrm{K} \& \mathrm{HCO} 3+\mathrm{CO} 3$

9- Concentration and precipitation

$\checkmark$ of $\mathrm{Na}+\mathrm{K}, \mathrm{HCO} 3+\mathrm{CO} 3 \mathrm{Cl}$

$+10-\mathrm{Cl}+\mathrm{SO} 4$ \& $\mathrm{HCO} 3+\mathrm{CO} 3$

11- Sea Water High $\mathrm{Na}+\mathrm{K} \& \mathrm{Cl}+\mathrm{SO} 4$

12- Water Contaminated with Gypsum

13- Static and Disco-ordinated Regimes

14- Dissolution \& Mixing

15- Dynamic and coordinated Regimes

Kusheshwar-Asthan

Fig. 9 Classification of hydrochemical facies (Kawar-Tal and Kusheshwar-Asthan) 
sufficient to support the biodiversity, but few locations are influenced by local anthropogenic activities which cause the increase of sulphur, chloride, iron and lead.

Acknowledgements We would like to thank School of Environmental Sciences (SES), Jawaharlal Nehru University (JNU), New Delhi, for providing valuable facility for sampling and analysis of water samples and thank Survey of India (SOI, New Delhi) and Indian Meteorological Department (IMD, New Delhi) for providing necessary data required for interpretation. At last, we would like to thank all my laboratory mates and authorities for providing necessary assistance during our research work in School of Environmental Sciences, Jawaharlal Nehru University, New Delhi. Thanks to all.

\section{References}

Ambastha K, Hussain AS, Badola R (2007) Resources dependence and attitudes of local people toward conservation of Kabartal wetland: a case study from the Indo-Gangetic plains. Wetlands Ecol Manag 15:287-302. doi:10.1007/s11273-006-9029-Z

American Public Health Association (APHA) (1995) Standard methods for the examination of water and waste water, 19th edn. American Public Health Association, Washington DC

Anand S, Joshi PK (2013) Remote sensing to quantify wetland loss. In: 14th ESRI India user conference, p 2

Araoye PA (2009) The seasonal variation of $\mathrm{pH}$ and dissolved oxygen (DO2) concentration in Asa lake Ilorin, Nigeria. Int J Phys Sci 4(5):271-274

Bell FG (1994) Engineering in rock masses. Butterworth and Heinemann Ltd., Frederic and Gladstone. ISBN 075061965 1, pp 92-786

Berner EK, Berner RA (1987) The global water cycle, geochemistry and environment. Prentice Hall, Englewood Cliffs, p 51

Bui EN, Mazullo J, Wilding LP (1990) Using quartz grain size and shape analysis to distinguish between aeolian and fluvial deposits in the Dallol Bosso of Niger (West Africa). Earth Surf Process Landf 14:157-166

Darling WG, Allen DJ, Armanson H (1990) Indirect detection of surface out flow from Rift Valley Lake. J Hydrol 113:297-305

De Voogt K, Kite G, Drooger P, Rust HM (2000) Modeling water allocation between wetland and irrigated agriculture. ISBN: 92-9090-407-0; p 1

Dewey JF, Bird JM (1970) Mountain belts and the new global tectonics. J Geophys Res 75:2625-2647

Edmond JM, Palwar MR, Measure CF, Grant B, Stallard RF (1995) The fluvial geochemistry and denudation rate of the Guayana Shield in Venezuela. Geochim Coscochim Acta 59:3301-3323

Folk RL, Ward WC (1957) Brazos River Bar, a study in the significance of grain size parameters. J Sediment Petrol 27:3-26

Friedman GM (1979) Differences in size distribution of population of particle among sands of various origins. Sedimentology 26:3-32

Garrel RM, Christ CL (1966) Solution minerals and equilibrium. Harper and Row, New York 1965, p 450

Garrel RM, Mackenzie FT (1967) Origin of the Chemical Composition of some springs and Lakes. In: Gould RF (ed) Equilibrium concepts in natural water systems. Advances in chemistry series, vol 67. American Chemical Society, Washington, DC, pp 223-242

Gibbs RJ (1970) Mechanism controlling world water chemistry. American Association for the Advancement of Science. Science, New Series, Vol. 170, No. 3962 (Dec. 4, 1970), pp 1088-1090

Giblin AE, Wieder RK (1992) Sulphur cycling in marine and freshwater wetlands. In: Howarth RW, Stewart JWB, Ivanov MW (eds) Sulphur cycling on the continents: wetlands, terrestrial ecosystem and associated water bodies, Scope 48 . Wiley, Chichester, pp 85-123

Goel PK, Trivedy RK, Bhave SV (1985) Studies on limnology of a few freshwater bodies in south-western Maharashtra with special reference to chemistry and pollution. Indian $\mathrm{J}$ Environ Prot $5(1): 19-25$

Goldman JC (1972) The effects of inorganic carbon on eutrophication. Presented at a seminar on eutrophication and biostimulation. California Department of Water Resources Proceeding, pp 3-53

Green MJB (1990) IUCN Directory of South Asian Protect Areas, IUCN Gland, Switzerland \& Cambridge. ISBN: 2-8317-0030-2, p 49

Guler C, Thyne GD, McCray JE, Turner AK (2002) Evaluation of graphical and multivariate statistical methods for classification of water chemistry data. J Hydrogeol 10:455-474

Hounslow AW (1995) Water quality data-analysis and interpretation. Lewis Publisher, A CRC Press Company, Boca Raton, Washington DC. ISBN 0 87371-676-0, pp 1-416

Huh Y, Tsoi M, Zaitiser A, Edward JN (1998) The fluvial geochemistry of the river of eastern Siberia. Tributaries of Lena River draining the sedimentation platform of the Siberia Craton. Geochim Coscochim Acta 62:1657-1676

Indian Meteorological Department (1990-2010) Data collected for temperature, rainfall, wind velocity, evapotranspiration, humidity etc from Meteorological. www.imd.gov.in/

Ingram RL (1971) Sieve analysis. In: Carver RE (ed) Procedures in sedimentology petrology. Wiley, New-York, pp 49-67

Irrigation \& Water ways Department (2000) http://wbiwd.gov.in/ index.php/applications/flood_mgmt

Jackson ML (1973) Soil chemical analysis: advanced courses, 2nd Edn. Parallel Press, University of Wisconsin, Wisconsin. ISBN 1-893311-47-3, pp 1-925

Kabata PA, Pendias H (1999) Biogeochemia pierwiastkow slodowych. PWN, Warszawa, pp 103-130

Kanwarlake.blogspot.com/2011_11_01_archive.html (2011)

King DL (1970) The role of carbon in eutrophication. J Water Pollut Control Fed 42(12):2035-2051

Krumbein W, Pettijohn F (1958) Manual of sedimentology petrography. Appleton-Century crofts Inc, New York, p 549

Lawrence JF, Balasubramanian A (1994) Groundwater condition and disposition of salt-fresh water interface in the Rameswaram island, Tamilnadu. Regional worshop on environmental aspects of groundwater development, Kurukshetra, pp 21-25

Lawrence FW, Upchurch SB (1982) Identification of recharge areas using geochemical factor analysis. Ground Water 20:680-687

Lindholm RC (1987) A practical approach to sedimentology. Crows Nest, Allen and Unwin, p 276. doi:10.1007/978-94-0117683-5 6

Mahadevan TM (2002). Geology of Bihar and Jharkhand. ISBN No: 81-85867-48-8, pp 1-564

Ministry of Environment and Forests (1989) Government of India. http://envfor.nic.in/legis/hsm/hsm3.htm

Munshi JSD, Munshi JD (1991) Physiographic of Kosi River basin and formation of wetland in the North Bihar: a unique fresh water system. J Freshw Bio 3(2):105-122

Nelson SA (2014) Weathering and clay minerals. EENS 2110:1-7

Nikanorov AM, Brazhnikova LV (1989) Water chemical composition of rivers, lakes and wetlands. Types Prop Water 2:1-11

Olsen RD, Summerfield MR (1977) The physical, chemical limnology of a Desert Reservoir, Hydrobiologia, vol. 53, 2nd edn. pp 117-129

Parkash B, Kumar S (1996) The Indogangetic Basin. Sedimentary Burins India Tectonic Contest 41:99-137

Ramasar (2007) http://www.ramsar.org/sites/default/files/documents/ library/info2007-01-e.pdf 
Ramsar Convention (2003) www.ramsar.org/sites/default/files/docu ments/pdf/key_strat_plan_2003_e.pdf

Sarana HM, Adoni AD (1982) Studies on the seasonal variation in $\mathrm{pH}$ and dissolved oxygen content in Sugar lake. Acta Botanica India 10:324-326

Scheper JS, Raun WR, Follet RF, Fox RH, Randall GW(2008) Nitrogen in agriculture system. American Society of Agronomy Inc. ISBN 978-0-89118-164-4, pp 1-947

Schuenemeyer JH, Drew LJ (2011) Statistics for earth and environment statistics. Wiley, Hoboken. doi:10.1002/9780470650707

Scott DA (Ed.) (1989) A directory of Asian wetlands. IUCN, Gland, Switzerland and Cambridge, UK, p 1181

Shapiro L, Brannock WW (1962) Rapid analysis of silicate, carbonate and phosphate rocks. U.S. Geological Survey Bulletin No 1144-A, p 56

Sharma UP (1995) Conservation management and sustainable development of Kawar-Lake wetland (Begusarai), Bihar (India) for rehabilitation of migratory birds. J Freshw Biol 73:217-224

Sharma UP, Pandey KN, Prakash V (1994) Ecology of fishes of Kawar lake wetland (Begusarai) Bihar. J Freshw Biol 61:49-55

Sigurdsson H (1990) Assessment of the atmospheric impact of volcanic eruptions. In: Sharpton VL, Ward PD(eds) Global catastrophes in earth history; and interdisciplinary conference on impacts, volcanism, and mass mortality. Geological Society of America, Special Paper 247, pp 99-110
Sinha AK, Barnah A, Singh DK, Sharma UP (1994) Bio-diversity and pollution status in relation to physicochemical factors of Kawar lake wetland (Begusarai), North Bihar. J Freshw Biol 64:309-315

Srivastava SK, Ramanathan AL (2012) Groundwater in vicinity of landfill, Application of graphical and multivariate statistical methods for hydrogeochemical characterization of Groundwater. Lambert Academic Publishing Germany, ISBN: 978-3-84732885-8, p 73

Taylor EW, Beale JF, Suckling EV, Thresh JC (1958) The examination of water and water supplied, 6th edn. Churchill, London

Wadia DN (1966) Geology of India (3rd Ed. rev.). MacMillan Company Ltd., London, Geological Magazine, 01/1939; 76(07). doi:10.1017/S0016756800071235

Wetzel RG (1974) The Phosphorus cycle, Limnology (Lake \& River Ecosystem) (3rd Ed.), Academic Press W. A Harcourt Science and Technology Company, San Diego San Francisco New York Boston London Sydney Tokyo, pp 242-250

Wetzel RG (1979) The role of the littoral zone and detritus in lake metabolism. Arch Hydrobiol Beih Ergeb Limnol 13:145-161

William JDH, Syers SK, Harris RF, Armstrong DE (1970) Fractionation of inorganic phosphate in calcareous lake sediments. Soil Sci Soc Am J 35(2):250-255

World Health Organization (2006) Guideline for drinking water quality, incorporating first addendum, vol 1, 3rd ed., ISBN 924 1546964 